University of New Hampshire

University of New Hampshire Scholars' Repository

6-1-1992

\title{
Interactions between carbon and nitrogen dynamics in estimating net primary productivity for potential vegetation in North America
}

\author{
A. David McGuire \\ University of Alaska \\ Jerry M. Melillo \\ Marine Biological Laboratory \\ L. A. Joyce \\ David W. Kicklighter \\ Marine Biological Laboratory (MBL) \\ Annette L. Schloss \\ University of New Hampshire, Durham, Annette.Schloss@unh.edu
}

See next page for additional authors

Follow this and additional works at: https://scholars.unh.edu/ersc

Comments

This is an article published by AGU in Global Biogeochemical Cycles in 1992, available online: https://dx.doi.org/

$10.1029 / 92 \mathrm{~GB} 00219$

\section{Recommended Citation}

McGuire, A., Melillo, J., Joyce, L., Kicklighter, D., Grace, A., Moore, B. III. and C. Vorosmarty. (1992). Interactions between carbon and nitrogen dynamics in estimating net primary productivity for potential vegetation in North America, Global BioGeoChem. Cyc., 6:101-124. https://dx.doi.org/10.1029/ 92GB00219

This Article is brought to you for free and open access by the Institute for the Study of Earth, Oceans, and Space (EOS) at University of New Hampshire Scholars' Repository. It has been accepted for inclusion in Earth Systems Research Center by an authorized administrator of University of New Hampshire Scholars' Repository. For more information, please contact Scholarly.Communication@unh.edu. 


\section{Authors}

A. David McGuire, Jerry M. Melillo, L. A. Joyce, David W. Kicklighter, Annette L. Schloss, Berrien Moore III, and Charles J. Vorosmarty

This article is available at University of New Hampshire Scholars' Repository: https://scholars.unh.edu/ersc/108 


\section{INTERACTIONS BETWEEN CARBON AND NITROGEN DYNAMICS IN ESTIMATING NET PRIMARY PRODUCTIVITY FOR POTENTIAL VEGETATION IN NORTH AMERICA}

\author{
A. D. McGuire, ${ }^{1,2}$ J. M. Melillo, ${ }^{1}$ L. A. Joyce, ${ }^{2}$ \\ D. W. Kicklighter, ${ }^{1}$ A. L. Grace, ${ }^{3}$ B. Moore III, ${ }^{3}$ \\ and C. J. Vorosmarty ${ }^{3}$
}

\begin{abstract}
We use the terrestrial ecosystem model (TEM), a process-based model, to investigate how interactions between carbon (C) and nitrogen (N) dynamics affect predictions of net primary productivity (NPP) for potential vegetation in North America. Data on pool sizes and fluxes of $\mathbf{C}$ and $\mathbf{N}$ from intensively studied field sites are used to calibrate the model for each of 17 non-wetland vegetation types. We use information on climate, soils, and vegetation to make estimates for each of 11,299 non-wetland, $0.5^{\circ}$ latitude $x$ $0.5^{\circ}$ longitude, grid cells in North America. The potential annual NPP and net N mineralization (NETNMIN) of North America are estimated to be $7.032 \times 10^{15} \mathrm{~g} \mathrm{C} \mathrm{yr}^{-1}$ and $104.6 \times 10^{12} \mathrm{~g} \mathrm{~N} \mathrm{yr}^{-1}$, respectively. Both NPP and NETNMIN increase along gradients of increasing temperature and moisture in northern and temperate regions of the continent, respectively. Nitrogen limitation of productivity is weak in tropical forests, increasingly stronger in temperate and boreal forests, and very strong in tundra ecosystems. The degree to which productivity is limited by the
\end{abstract}

\footnotetext{
${ }^{1}$ The Ecosystems Center, Marine Biological

Laboratory, Woods Hole, Massachusetts.

Hampshire, Durham.

Copyright 1992

by the American Geophysical Union.

Paper number 92GB00219.

$0886-6236 / 92 / 92$ GB- $00219 \$ 10.00$
}

${ }^{2}$ Rocky Mountain Forest and Range Experiment

Station, USDA Forest Service, Fort Collins, Colorado.

${ }^{3}$ Center for Complex Systems, Institute for the Study

of Earth, Oceans, and Space, University of New availability of $\mathbf{N}$ also varies within ecosystems. Thus spatial resolution in estimating exchanges of $\mathrm{C}$ between the atmosphere and the terrestrial biosphere is improved by modeling the linkage between $\mathrm{C}$ and $\mathrm{N}$ dynamics. We also perform a factorial experiment with TEM on temperate mixed forest in North America to evaluate the importance of considering interactions between $\mathrm{C}$ and $\mathrm{N}$ dynamics in the response of NPP to an elevated temperature of $2^{\circ} \mathrm{C}$. With the $\mathrm{C}$ cycle uncoupled from the N cycle, NPP decreases primarily because of higher plant respiration. However, with the $C$ and $\mathrm{N}$ cycles coupled, NPP increases because productivity that is due to increased $\mathbf{N}$ availability more than offsets the higher costs of plant respiration. Thus, to investigate how global change will affect biosphereatmosphere interactions, process-based models need to consider linkages between the $\mathrm{C}$ and $\mathrm{N}$ cycles.

\section{INTRODUCTION}

Terrestrial ecosystems play a major role in the global carbon budget. Through the process of photosynthesis, land plants annually remove between 90 and $120 \times 10^{15} \mathrm{~g}$ carbon from the atmosphere [Houghton et al., 1985]. This is about 20 times more carbon than is emitted to the atmosphere during fossil fuel combustion. Approximately half of the carbon taken up by plants is returned to the atmosphere during plant respiration, and the remainder, known as net primary productivity (NPP), is incorporated into plant matter. Humans are dependent on a fraction of this NPP for food, fuel, and fiber.

Global change has the potential to alter the magnitude and temporal and spatial patterns of NPP for the terrestrial biosphere. Changes in a variety of factors including temperature, moisture, cloudiness, 
atmospheric $\mathrm{CO}_{2}$ concentration, nutrient inputs in precipitation, and land-use patterns will affect NPP. These changes may alter productivity by affecting plant physiology and/or nutrient cycling rates. An important challenge is to develop the ability to predict how global change will affect NPP. Working toward this goal, we have developed the terrestrial ecosystem model (TEM) [Raich et al., 1991].

The TEM is a process-based model that was designed to estimate the spatial and temporal distribution of major carbon (C) and nitrogen (N) fluxes and pool sizes at continental to global scales. It was first applied to estimate the net primary productivity of potential vegetation in South America [Raich et al., 1991]. Although the spatial and temporal predictions of NPP in South America were evaluated by Raich et al. [1991], interactions between the $\mathrm{C}$ and $\mathrm{N}$ cycles in estimating productivity were not explicitly explored. Because much of the Amazon Basin is covered with phosphorousdeficient soils [Sanchez et al., 1982], this evaluation was not appropriate for South America.

In many northern and temperate ecosystems, NPP is known to be limited by the availability of inorganic $N$ [Mitchell and Chandler, 1939; Safford and Filip, 1974; Van Cleve and Zasada, 1976; Auchmoody and Smith, 1977; Dodd and Lauenroth, 1979; Ellis, 1979; Shaver and Chapin, 1980; Risser et al., 1981; Aber et al., 1982; Peterson, 1982; Pastor et al., 1984; Chapin et al., 1986; Shaver and Chapin, 1986; Chapin, 1991a; Vitousek and Howarth, 1991]. In North America these ecosystems have been well studied relative to other continents. Patterns of NPP are understood, at least qualitatively, along north-south temperature gradients in northern North America and east-west moisture gradients in temperate North America. These gradients provide an opportunity to qualitatively check predictions of NPP and to examine how the strength of the linkages between $C$ and $N$ dynamics varies spatially. In this study we apply TEM to North America and evaluate how interactions between the $C$ and $N$ cycles affect predictions of NPP.

Interactions between the $\mathrm{C}$ and $\mathrm{N}$ cycles are predicted to be important in the response of some ecosystems to elevated temperature [Pastor and Post, 1986, 1988; Bonan et al., 1990; Schimel et al., 1990; Nadelhoffer et al., 1991; Rastetter et al., 1991]. We were interested in evaluating the importance of considering the linkage between $\mathbf{C}$ and $\mathbf{N}$ dynamics in predicting the response of NPP. We do this by performing a factorial experiment on temperate mixed forest in North America in which we run TEM under different temperature scenarios with the $C$ and $N$ cycles either coupled or uncoupled.

\section{MODEL DESCRIPTION AND MODIFICATIONS}

\section{Model Description}

The TEM uses spatially referenced information (resolution: $0.5^{\circ}$ latitude $\mathrm{x} 0.5^{\circ}$ longitude) on climate, soils, and vegetation to make monthly estimates of important $\mathrm{C}$ and $\mathrm{N}$ fluxes and pool sizes. TEM is a highly aggregated model (Figure 1 ) that consists of five pools ( $C$ in vegetation, $N$ in vegetation, $C$ in soil, organic $\mathrm{N}$ in soil, inorganic $\mathrm{N}$ in soil) and nine fluxes (gross primary productivity, plant respiration, $\mathrm{C}$ in litter production, soil respiration, $\mathbf{N}$ input to the ecosystem, $\mathrm{N}$ uptake by vegetation, $\mathbf{N}$ in litter production, net $\mathbf{N}$ mineralization, $\mathrm{N}$ lost from the ecosystem).

The basic strategy in extrapolating TEM for a region is to run the model to equilibrium for each grid cell $\left(0.5^{\circ}\right.$ latitude $\times 0.5^{\circ}$ longitude). Running the model for a particular grid cell requires the use of monthly climatic data and the soil-and vegetation-specific parameters appropriate to the grid cell. The water balance model (WBM) of Vorosmarty et al. [1989] is used to produce hydrologic inputs for TEM. Although some of the vegetation-specific parameters in the model can be defined from published information, others must be determined by calibrating the model to the steady state fluxes and pool sizes of an intensively studied field site, the calibration site (see Table 1).

The version of the model applied to South America is fully described by Raich et al. [1991]. We have made several modifications to the original model. Foremost among these is the design of a new feedback algorithm between $\mathrm{C}$ and $\mathrm{N}$ uptake. Other changes involve calculation of $\mathrm{N}$ in litter production, temperature effects on gross primary productivity and plant maintenance respiration, and leaf conductivity to carbon dioxide in arid regions.

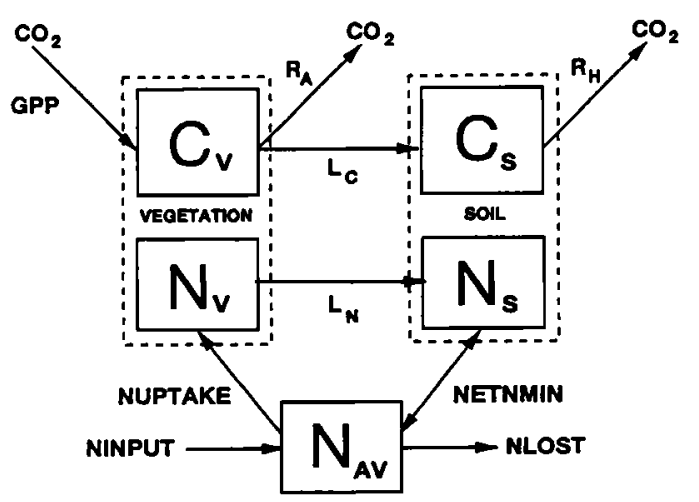

Fig. 1. The terrestrial ecosystem model (TEM). The state variables are: carbon in vegetation $\left(C_{V}\right)$; nitrogen in vegetation $\left(\mathrm{N}_{\mathrm{V}}\right)$; organic carbon in soils and detritus $\left(C_{S}\right)$; organic nitrogen in soils and detritus $\left(\mathrm{N}_{S}\right)$; and available soil inorganic $\mathbf{N}\left(\mathbf{N}_{\mathrm{AV}}\right)$. Arrows show carbon and nitrogen fluxes: GPP, gross primary productivity; $\mathbf{R}_{A}$, autotrophic respiration; $\mathbf{R}_{\mathrm{H}}$, heterotrophic respiration; $\mathrm{L}_{\mathrm{C}}$, litterfall $\mathrm{C}$; $\mathrm{L}_{\mathrm{N}}$, litterfall $\mathrm{N}$; NUPTAKE, $\mathrm{N}$ uptake by vegetation; NETNMIN, net $\mathrm{N}$ mineralization of soil organic $N$; NINPUT, $N$ inputs from outside the ecosystem; and NLOST, $\mathrm{N}$ losses from the ecosystem. 
TABLE 1. Study Sites From Which Data Was Gathered and Used to Calibrate Some of the Vegetation-Specific Parameters in the Terrestrial Ecosystem Model

\begin{tabular}{llrr}
\hline Site Name & \multicolumn{1}{c}{ Vegetation Type } & Location \\
\hline Toolik Lake (USA) & polar desert/alpine tundra & $65^{\circ} 26^{\prime} \mathrm{N}$, & $145^{\circ} 30^{\prime} \mathrm{W}$ \\
Toolik Lake (USA) & wet/moist tundra & $65^{\circ} 26^{\prime} \mathrm{N}$, & $145^{\circ} 30^{\prime} \mathrm{W}$ \\
Schefferville (Canada) & boreal woodland & $54^{\circ} 43^{\prime} \mathrm{N}$, & $66^{\circ} 42^{\prime} \mathrm{W}$ \\
Bonanza Creek (USA) & boreal forest & $64^{\circ} 45^{\prime} \mathrm{N}$, & $148^{\circ} 15^{\prime} \mathrm{W}$ \\
H. J. Andrews (USA) & temperate coniferous forest & $44^{\circ} 15^{\prime} \mathrm{N}$, & $122^{\circ} 20^{\prime} \mathrm{W}$ \\
Curlew Valley (USA) & arid shrubland & $41^{\circ} 05^{\prime} \mathrm{N}$, & $113^{\circ} 05^{\prime} \mathrm{W}$ \\
Pawnee (USA) & short grassland & $40^{\circ} 49^{\prime} \mathrm{N}$, & $104^{\circ} 46^{\prime} \mathrm{W}$ \\
Osage (USA) & tall grassland & $36^{\circ} 57^{\prime} \mathrm{N}$, & $96^{\circ} 33^{\prime} \mathrm{W}$ \\
Cedar Creek (USA) & temperate savanna & $45^{\circ} 35^{\prime} \mathrm{N}$, & $93^{\circ} 10^{\prime} \mathrm{W}$ \\
Harvard Forest (USA) & temperate deciduous forest & $42^{\circ} 32^{\prime} \mathrm{N}$, & $72^{\circ} 10^{\prime} \mathrm{W}$ \\
Harvard Forest (USA) & temperate mixed forest & $42^{\circ} 32^{\prime} \mathrm{N}$, & $72^{\circ} 10^{\prime} \mathrm{W}$ \\
Taita (New Zealand) & temperate broadleaved evergreen forest & $41^{\circ} 11^{\prime} \mathrm{S}$, & $174^{\circ} 58^{\prime} \mathrm{E}$ \\
Nylsvley (South Africa) & tropical savanna & $24^{\circ} 39^{\prime} \mathrm{S}$, & $28^{\circ} 42^{\prime} \mathrm{E}$ \\
Guanica (Puerto Rico) & xeromorphic woodland & $1^{\circ} 55^{\prime} \mathrm{N}$, & $66^{\circ} 55^{\prime} \mathrm{W}$ \\
Chakia (India) & tropical deciduous forest & $25^{\circ} 20^{\prime} \mathrm{N}$, & $83^{\circ} 00^{\prime} \mathrm{E}$ \\
Ducke (Brazil) & tropical evergreen forest & $2^{\circ} 50^{\prime} \mathrm{S}$, & $59^{\circ} 57^{\prime} \mathrm{W}$ \\
\hline
\end{tabular}

\section{Feedback Between $C$ and $N$ Uptake by the Vegetation}

In the initial version of TEM, feedback between $C$ and $\mathrm{N}$ uptake by the vegetation was designed to maintain the vegetation $C$ to $N$ ratio at a target ratio that was specific to the vegetation type. This was accomplished by allowing the vegetation to acclimate to the environment of the grid cell by adjusting allocation of effort between $\mathrm{C}$ and $\mathrm{N}$ uptake. This is analagous to adjusting the shoot to root ratio of the vegetation.

This feedback algorithm, although interesting from the perspective of allocation theory, has several drawbacks. First, because the rate of acclimation in the model is chosen arbitrarily, the algorithm can only be used to find the equilibrium solution of a grid cell; the transient response may be inappropriate. Second, the algorithm is not designed to respond to changes in carbon-nitrogen balance that occur on a monthly time scale; use of the model to look at seasonal exchanges of gases with the atmosphere requires subannual feedback. Finally, $\mathrm{C}$ to $\mathrm{N}$ ratios of many vegetation types are known to change during succession. This is especially the case for forests in which C-rich heartwood increases through succession resulting in an increasing $\mathrm{C}$ to $\mathrm{N}$ ratio. To assist in future development of a successional version of TEM, we needed to modify the model so that the aggregated $\mathrm{C}: \mathrm{N}$ of vegetation was not maintained as a constant. We therefore designed a new feedback algorithm between $\mathrm{C}$ and $\mathrm{N}$ uptake.

Photosynthesis is known to decrease when the availability of inorganic $\mathrm{N}$ is restricted [Chapin, 1980; Evans, 1983; Clarkson, 1985; Chapin et al., 1988; Chapin, 1991b]. This response is the result of the feedback of $N$ availability on $C$ uptake. The $C$ to $N$ ratio of new production $\left(\mathrm{P}_{\mathrm{cn}}\right)$ is commonly measured in ecosystem studies, and this information can be used by TEM to determine when the vegetation is stressed by the availability of $\mathrm{N}$ : if the calculated $\mathrm{C}$ to $\mathrm{N}$ ratio of production (PPROD ${ }_{\mathrm{cn}}$, the potential $\mathrm{C}$ to $\mathrm{N}$ ratio of production) is greater than $P_{c n}$, then the vegetation is stressed by the availability of $N$. We expect photosynthesis to monotonically decrease as $\mathrm{N}$ stress increases. This relationship, as we have described it, is a feedback curve of the effect of $\mathbf{N}$ availability on $\mathbf{C}$ uptake.

If the relationship is scaled to decrease from 1 to 0 as $N$ stress increases, then the feedback curve $f(N A)$ can be used in the GPP equation to quantify the effect of $N$ availability on $\mathrm{C}$ uptake (similar to the effects of other factors):

$G P P=C_{\max } f(P A R) f\left(\mathrm{CO}_{2}, \mathrm{H}_{2} \mathrm{O}\right) f(L E A F) f(T) f(N A)$

where $\mathrm{C}_{\max }$ is the maximum rate of $\mathrm{C}$ assimilation, PAR is photosynthetically active radiation, LEAF (i.e., leaf phenology) is leaf area relative to the maximum leaf area, $T$ is temperature, and NA is nitrogen availability. We assume that the shape of $\mathbf{f}(\mathrm{NA})$ is parabolic (Figure 2). The amount of $C$ potentially available for production is the calculated NPP based on GPP with $f(N A)$ set to 1 . The point at which $f(N A)$ becomes 0 , the parameter $\mathrm{CN}_{\max }$ is important in quantifying the severity of the feedback.

If, after applying $f(N A)$ on the calculation of GPP, the resulting NPP to $N$ uptake ratio falls below $P_{c n}$, then feedback is curtailed during model operation so that the ratio equals $\mathbf{P}_{\mathrm{cn}}$. Thus the photosynthetic machinery is only slowed to the point at which the vegetation takes up enough $\mathbf{C}$ to match $\mathbf{N}$ uptake. For the case when the final NPP to $N$ uptake ratio is greater than $P_{c n}$, the additional $\mathrm{N}$ required to build tissue is implicitly assumed to come from the recycling of $\mathbf{N}$ within the vegetation. On an annual basis this means that $\mathrm{N}$ in production must equal the sum of $\mathbf{N}$ in uptake and recycled $N$. This aspect of the feedback algorithm is 


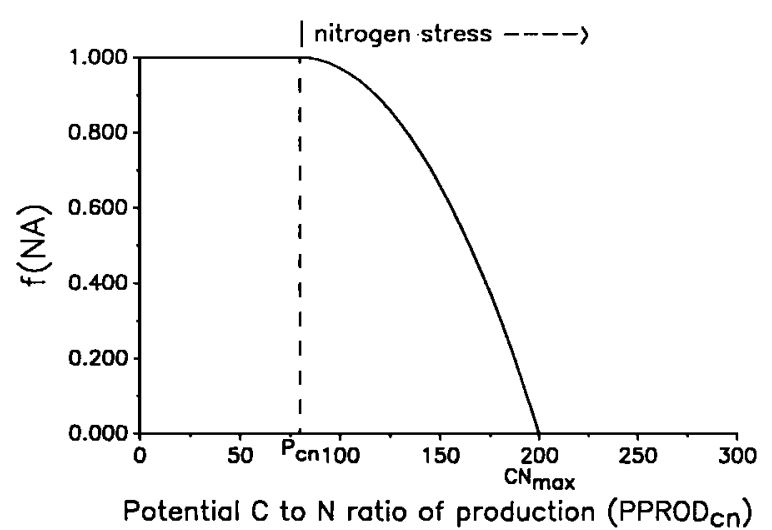

Fig. 2. Effect of nitrogen availability (NA) on the relative uptake of $C$ by the vegetation [ $f(N A)]$, i.e., relative GPP. Nitrogen stress increases as the potential $\mathrm{C}$ to $\mathrm{N}$ ratio of production (PPROD $\mathrm{cn}$ ) rises above $\mathrm{P}_{\mathrm{cn}}$, the annual $\mathrm{C}$ to $\mathrm{N}$ of production at the calibration site. When PPROD $_{c n}$ is less than $P_{c n}, f(N A)$ is unaffected. As PPROD $_{c n}$ increases above $P_{c n}, f(N A)$ decreases according to a parabolic function. The calibrated parameter $\mathrm{CN}_{\max }$, which describes the severity of the feedback, is the point at which $\mathrm{f}(\mathrm{NA})$ goes to 0 .

particularly important in the $\mathrm{N}$ cycle of arctic and subarctic ecosystems, where recycling of $\mathrm{N}$ by the vegetation is substantial [Chapin et al., 1980; Chapin and Kedrowski, 1983; Jonasson and Chapin, 1985; Shaver et al., 1990; Chapin and Moilanen, 1991; Shaver and Chapin, 1991].

Similar to the effect of $\mathrm{N}$ availability on $\mathrm{C}$ uptake, the uptake of $\mathrm{N}$ should monotonically decrease as the potential $\mathrm{C}$ to $\mathrm{N}$ ratio of production decreases below $P_{c n}$, i.e., the uptake of $\mathbf{N}$ should decrease as $\mathrm{C}$ stress increases. We have incorporated this relationship into the equation for $\mathrm{N}$ uptake as the parabolic function $\mathbf{f}(\mathrm{CA})$ :

$$
\text { NUPTAKE }=\mathrm{N}_{\max } \mathrm{f}\left(\text { inorganic } \mathrm{N}, \mathrm{H}_{2} \mathrm{O}\right) \mathrm{f}(\mathrm{T}) \mathrm{f}(\mathrm{CA})
$$

where $\mathrm{N}_{\max }$ is the maximum rate of $\mathrm{N}$ uptake by the vegetation, $T$ is temperature, and $C A$ is carbon availability. The amount of $N$ potentially available for production is determined with $\mathrm{f}(\mathrm{CA})$ set to 1 . In the implementation of this feedback, $f(C A)$ goes to 0 as NPP goes to 0 .

\section{$N$ in Litter Production}

In the previous version of TEM, $\mathrm{N}$ in litter production was controlled to maintain the $\mathrm{C}$ to $\mathrm{N}$ ratio of the vegetation at a target ratio. Because we are not directly controlling the $\mathrm{C}$ to $\mathrm{N}$ ratio of vegetation in this version of TEM, we changed the calculation of this flux. We calculate the amount of $\mathrm{N}$ in litter production similar to the calculation of the amount of $\mathrm{C}$ in litter production:
NFALL $=\frac{\text { (annual N uptake) }}{12\left(\text { mean annual } N_{\mathrm{v}}\right)}$

$\mathrm{L}_{\mathrm{Nt}}=\mathrm{N}_{\mathrm{Vt}}(\mathrm{NFALL})$

where annual $\mathrm{N}$ uptake and mean annual $\mathrm{N}_{\mathrm{V}}$ are defined from literature sources for the specific sites used to calibrate TEM, and $\mathrm{L}_{\mathrm{Nt}}$ and $\mathrm{N}_{\mathrm{Vt}}$ are the amount of $\mathrm{N}$ in litter production and vegetation, respectively, at the time step $t$. The parameter NFALL is assumed to be constant within each vegetation type. This algorithm causes $\mathrm{L}_{\mathrm{N}}$ to track seasonal changes in $\mathrm{N}_{\mathrm{V}}$.

\section{Temperature Effects on Gross Primary Productivity}

In the initial version of TEM the temperature effects on gross primary production (GPP) were assumed to be the same as the measured effects on net photosynthesis. This was modeled with a parabolic function that rose from 0 to 1 between the minimum and optimum temperatures for photosynthesis and decreased from 1 to 0 between the optimum and maximum temperatures for photosynthesis. Although the shape of this relationship is reasonable for net photosynthesis, which is the difference between gross photosynthesis and leaf respiration, it is not appropriate for gross photosynthesis. Because of photorespiration, gross photosynthesis generally approaches an asymptote as temperature increases [Larcher, 1980; Fitter and Hay, 1981] and does not decrease until temperatures are high enough to cause denaturing of photosynthetic enzymes. In the current version of TEM we allowed the temperature effects on GPP to increase from 0 to 1 between the minimum and optimum temperature of photosynthesis as in the original version of TEM but maintained the temperature multiplier of GPP to be 1 above the optimum temperature. We did not simulate the denaturing effects of temperature because the temperatures in our climatic data sets never rise into the region of denaturation. Even if the temperatures were to rise into the denaturing region, other factors in the model would invariably cause GPP to drop to very small values.

\section{Temperature Effects on Plant Maintenance Respiration}

As in the initial version of TEM, we model plant maintenance respiration $\left(\mathbf{R}_{\mathrm{m}}\right)$ as follows:

$R_{m}=K_{r}\left(C_{V}\right) e^{\left(r_{T}\right) T}$

where $\mathrm{K}_{\mathrm{r}}$ is the per-gram-biomass respiration rate of the vegetation at $0^{\circ} \mathrm{C}, \mathrm{C}_{\mathrm{V}}$ is the mass of carbon in the vegetation, $T$ is the mean monthly air temperature, and $r_{T}$ is the instantaneous rate of change in respiration. In the initial version of TEM, $r_{T}$ was determined by assuming that $Q_{10}$, the rate of change in respiration due to a $10^{\circ}$ increase in temperature, is 2 . Because $r_{T}=$ $\operatorname{Ln}\left(Q_{10}\right) / 10$, this resulted in $r_{T}$ of 0.0693 . The measured 
values of $Q_{10}$ are commonly around 2 in the region of $5^{\circ}-20^{\circ} \mathrm{C}$ but below $5^{\circ} \mathrm{C}$ become greater and above $20^{\circ} \mathrm{C}$ fall off to 1.5 or less [Larcher, 1980]. We assumed a linear increase of $\mathrm{Q}_{10}$ from 2.0 to 2.5 between $5^{\circ}$ and $0^{\circ}$ C, a constant $Q_{10}$ of 2.0 between $5^{\circ}$ and $20^{\circ} \mathrm{C}$, and a linear decrease of $Q_{10}$ from 2.0 to 1.5 between $20^{\circ}$ and $40^{\circ}$. We modeled this temperature dependence with a third-order polynomial regression using integer values of temperature between $0^{\circ}$ and $40^{\circ} \mathrm{C}$ to obtain the smooth relationship:

$Q_{10}=2.35665-0.05308 T+0.00238 T^{2}-0.00004 T^{3}$

where $\mathrm{T}$ is the mean monthly temperature.

\section{Leaf Conductivity to Carbon Dioxide in Arid Regions}

$\mathrm{G}_{\mathrm{V}}$, the unitless multiplier in the model that causes leaf conductivity to $\mathrm{CO}_{2}$ to change in response to moisture availability, was modified for EET/PET $\leq 0.1$, as follows:

$\mathrm{G}_{\mathrm{V}}=-10(\mathrm{EET} / \mathrm{PET})^{2}+2.9(\mathrm{EET} / \mathrm{PET})$

where EET is estimated evapotranspiration and PET is potential evapotranspiration. This function allows the minimum possible $G_{V}$ to be 0 instead of 0.1 , a plant response that seems possible in extremely arid regions. For EET/PET $>0.1$, calculation of $G_{V}$ is the same as in the work by Raich et al. [1991]. The shape of the new function allows the slopes to match at EET/PET $=0.1$.

\section{METHODS}

\section{Parameterization of TEM}

Parameters in TEM are vegetation-specific (Tables 2 and 3), soil-specific (Table 4), or constant [see Raich et al., 1991]. We defined the vegetation-specific parameters of the leaf phenology submodel (see Table 2) based on data from numerous phenology studies. To define the parameters that determine the response of gross primary production to temperature for each vegetation type $\left(\mathrm{T}_{\min }\right.$ and $\mathrm{T}_{\text {opt }}$; see Table 3 ), we used information compiled by Larcher [1980].

We used data from intensively studied field sites to estimate the remaining vegetation-specific parameters (see Table 3) for 16 non-wetland ecosystems (see appendix for compilation of data). Mediterranean shrubland, another ecosystem considered by TEM, uses the same calibrated parameters as xeromorphic woodland. However, the two ecosystems have different parameters for the leaf phenology submodel. The WBM does not adequately represent the water balance for ecosystems with permafrost (i.e., boreal forest, boreal woodland, wet/moist tundra, polar desert/alpine tundra). For these ecosystems we calibrated and ran the model with soil moisture equal to field capacity and estimated evapotranspiration equal to potential evapotranspiration.

Fertilization studies in natural ecosystems have often been conducted to determine the degree to which NPP is limited by $\mathrm{N}$ availability. We used data on the

TABLE 2. Values of Parameters Used to Estimate the Relative Photosynthetic Capacity of the Vegetation, $f(L E A F)$

\begin{tabular}{lcccc}
\hline \multicolumn{1}{c}{ Vegetation Type } & & \multicolumn{2}{c}{ Parameter } & \\
\cline { 2 - 5 } & $\mathrm{a}$ & $\mathrm{b}$ & $\mathrm{c}$ & $\mathrm{min}$ \\
\hline Polar desert/alpine tundra & 0.7964 & 0.4664 & -0.0287 & 0.00 \\
Wet/moist tundra & 0.7964 & 0.4664 & -0.0287 & 0.00 \\
Boreal woodland & 0.7149 & 0.2944 & 0.1329 & 0.20 \\
Boreal forest & 0.4289 & 0.3330 & 0.3223 & 0.50 \\
Temperate coniferous forest & 0.0000 & 0.0000 & 0.0000 & 1.00 \\
Arid shrubland & 0.4640 & 0.6708 & -0.0068 & 0.25 \\
Short grassland & 0.4437 & 0.6520 & 0.0098 & 0.10 \\
Tall grassland & 0.4746 & 0.5807 & -0.0564 & 0.05 \\
Temperate savanna & 0.7808 & 0.4427 & -0.0828 & 0.05 \\
Temperate deciduous forest & 0.8330 & 0.3520 & -0.0754 & 0.02 \\
Temperate mixed forest & 0.4162 & 0.3516 & 0.2874 & 0.50 \\
Temperate broadleaved evergreen forest & 0.0000 & 0.0000 & 0.0000 & 1.00 \\
Mediterranean shrubland & 0.2669 & 0.9592 & -0.0773 & 0.25 \\
Tropical savanna & 0.3366 & 0.6451 & 0.0422 & 0.15 \\
Xeromorphic woodland & 0.4423 & 0.5426 & 0.0713 & 0.25 \\
Tropical deciduous forest & 0.4423 & 0.5426 & 0.0713 & 0.25 \\
Tropical evergreen forest & 0.4423 & 0.5426 & 0.0713 & 0.25 \\
\hline
\end{tabular}

Parameters are defined by Raich et al. [1991]. 


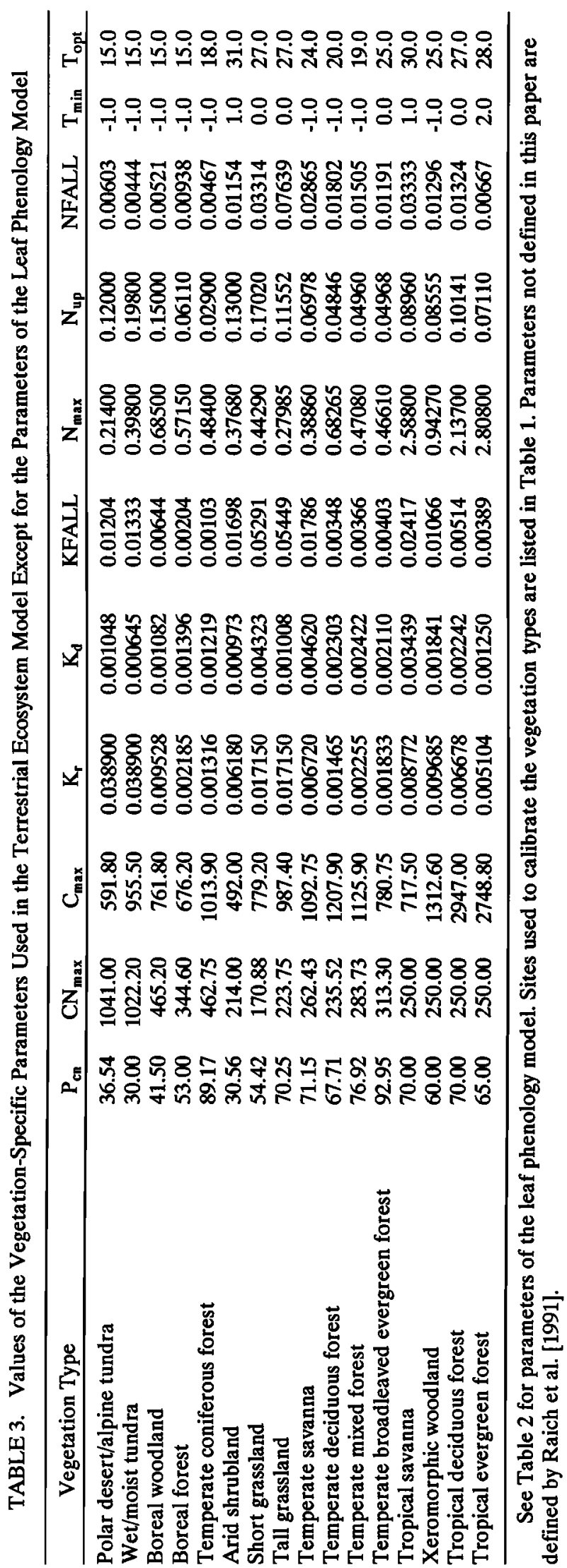

maximum response of NPP to $\mathrm{N}$ fertilization (NPPSAT in the tables of the appendix) to determine, and therefore constrain, the maximum rate of $\mathrm{C}$ assimilation by the vegetation, i.e., the parameter $\mathrm{C}_{\max }$ in the GPP equation. With this information in TEM we are able to run the $\mathrm{C}$ cycle uncoupled from the $\mathrm{N}$ cycle to determine productivity as if $\mathrm{N}$ were not limiting.

For the calibration sites that were determined to be $\mathrm{N}$ limited, i.e., the first 12 ecosystems in Table 1, we calculated $P_{c n}$ as the ratio of NPP to $N$ in production; $N$ in production is assumed to equal the sum of

NUPTAKE and NMOBIL in the tables of the appendix. The parameter $\mathrm{CN}_{\max }$ was then determined for these ecosystems by calibrating the model to the equilibrium pools and fluxes of the calibration site. This procedure assumes that $\mathrm{N}$ in production equals $\mathrm{N}$ required for production, i.e., "N requirement." However, for systems that are not $\mathbf{N}$ limited, $\mathrm{N}$ in production may not reflect $\mathrm{N}$ requirement because of the possibility of luxury $\mathbf{N}$ uptake. We calibrated the tropical and subtropical ecosystems, i.e., the last four ecosystems in Table 1 , as if they were not $\mathrm{N}$ limited. For these calibrations we set $\mathrm{CN}_{\max }$ to 250 , a value approximately equal to that for temperate deciduous forest, and adjusted $P_{c n}$ upward from the ratio of NPP to $\mathrm{N}$ in production until there was no $\mathrm{N}$ limitation.

An estimate of gross primary production (GPP) is required to calibrate a parameter in the plant respiration equation. In cases where the GPP budget of the calibration site was lacking, we used the method of Ryan [1991a] to estimate GPP. This method determines a gross production budget by estimating the following quantities: net primary production and associated construction respiration of aboveground wood and foliage, aboveground maintenance respiration, and belowground carbon allocation. Aboveground wood and foliage production are determined from field studies and construction respiration is estimated to be $25 \%$ of production. Empirical relationships between respiration and structural nitrogen [Ryan, 1991b] are used to estimate aboveground maintenance respiration. Belowground carbon allocation is estimated from fine litterfall using an empirical relationship [Raich and Nadelhoffer, 1989].

In this version of TEM, field capacities for different soil textures (FC in Table 4) were defined from Ratliff et al. [1983] rather than from Saxton et al. [1986]; the estimates of the former are based on field studies, whereas those of the latter are based on laboratory studies. The soil-specific parameters that define the influence of soil moisture on decomposition were defined for the new field capacities as described by Raich et al. [1991].

In the initial version of TEM the half-saturation constant for the effect of atmospheric $\mathrm{CO}_{2}$ concentration on GPP was chosen to yield a $23 \%$ increase with a doubling of $\mathrm{CO}_{2}$. This value is at the low end of those obtained in empirical studies that provided adequate nutrients and water to plants (range 24 to $50 \%$ [see Raich et al., 1991]). In this version of TEM we chose an intermediate yield of $37 \%$ to define this parameter. 
TABLE 4. Values of Soil-Specific Parameters Used in the Terrestrial Ecosystem Model

\begin{tabular}{lccccc}
\hline \multirow{2}{*}{ Parameter } & \multicolumn{5}{c}{ Texture } \\
\cline { 2 - 6 } & Sand & Sandy Loam & Loam & Clay Loam & Clay \\
\hline FC (\% saturation) & 54.0 & 58.0 & 62.0 & 63.0 & 64.0 \\
$\mathrm{M}_{\text {opt }}$ (\% saturation) & 62.0 & 65.0 & 68.0 & 71.0 & 73.0 \\
$\mathrm{~m} 1$ & 0.350 & 0.044 & -0.289 & -0.425 & -0.732 \\
$\mathrm{M}_{\text {sat }}$ & 0.5000 & 0.5625 & 0.6250 & 0.6875 & 0.7500 \\
\hline
\end{tabular}

Parameters are defined by Raich et al. [1991].

\section{Application of TEM to North America}

The sources for the air temperature, cloudiness, elevation, precipitation, and soil texture data that we used for North America are described by Raich et al. [1991]. We used the water balance model (WBM) of Vorosmarty et al. [1989] with refinements by E. B. Rastetter (personal communication, 1991) to produce estimates of potential evapotranspiration, actual evapotranspiration, and soil moisture. Monthly data sets of photosynthetically active radiation and relative leaf phenology were generated as described by Raich et al. [1991]. As in the application of the model to South America, we set the monthly atmospheric concentration of $\mathrm{CO}_{2}$ to $340 \mathrm{ppmv}$ for all grid cells. We also assumed $\mathrm{N}$ inputs and losses to be negligible in each grid cell.

Each of the 12,260 grid cells in North America was assigned to an ecosystem type (Plate 1). For Alaska, Canada, and the continental United States we digitized maps of potential, i.e., undisturbed natural, vegetation to a resolution of $0.5^{\circ}$ latitude $x 0.5^{\circ}$ longitude [Joint Federal-State Land Use Planning Commission for Alaska, 1973; Rowe, 1972; Kuchler, 1964]. For Mexico and Central America we modified an extant $1^{\circ} \times 1^{\circ}$ data set [Matthews, 1983] to more accurately represent transitions between vegetation types at the $0.5^{\circ} \times 0.5^{\circ}$ resolution. The 11,299 grid cells for which we ran the model account for $93.8 \%$ of the $22.14 \times 10^{6} \mathrm{~km}^{2}$ in North America. We did not make predictions for ice, wetland ecosystems, and open water.

For extrapolating TEM the run for each grid cell starts with the January values of the driving variables. Therefore the initial values of the pools for a grid cell were set equal to those of December from the appropriate vegetation-specific calibration (Table 5). A grid cell was determined to have reached equilibrium when the annual fluxes of NPP, $C$ in litter production, and soil respiration differed by less than $1 \mathrm{gC} \mathrm{m}^{-2} \mathrm{yr}^{-1}$, and those of NETNMIN, $\mathrm{N}$ uptake by vegetation, and $\mathrm{N}$ in litter production differed by less than $0.01 \mathrm{gN} \mathrm{m}^{-2} \mathrm{yr}^{-1}$.

\section{Experiment Examining the Interactions of $C$ and $N$ in the Response of NPP to Elevated Temperature}

We used TEM in a factorial experiment on temperate mixed forest in North America to examine interactions

TABLE 5. Initial Values of the State Variables for Extrapolating the Terrestrial Ecosystem Model to Grid Cells Within Each Vegetation Type

\begin{tabular}{lrrrrr}
\hline \multicolumn{1}{c}{ Vegetation Type } & \multicolumn{1}{c}{$\mathrm{C}_{\mathrm{V}}$} & $\mathrm{N}_{\mathrm{V}}$ & \multicolumn{1}{c}{$\mathrm{C}_{\mathrm{S}}$} & $\mathrm{N}_{\mathrm{S}}$ & $\mathrm{N}_{\mathrm{AV}}$ \\
\hline Polar desert/alpine tundra & 454.20 & 6.53 & 5997.40 & 259.92 & 0.42 \\
Wet/moist tundra & 757.69 & 15.05 & 17997.88 & 1099.70 & 0.41 \\
Boreal woodland & 2208.73 & 24.10 & 13340.88 & 735.16 & 0.51 \\
Boreal forest & 9006.52 & 20.06 & 10991.50 & 370.11 & 0.68 \\
Temperate coniferous forest & 43496.64 & 75.02 & 21011.28 & 420.03 & 0.96 \\
Arid shrubland & 533.51 & 19.50 & 10994.65 & 799.59 & 1.68 \\
Short grassland & 324.38 & 8.89 & 3805.65 & 389.61 & 2.24 \\
Tall grassland & 675.25 & 6.15 & 16016.03 & 1549.38 & 4.38 \\
Temperate savanna & 2120.73 & 16.28 & 4337.19 & 399.51 & 4.37 \\
Temperate deciduous forest & 15596.35 & 37.42 & 11227.59 & 558.93 & 2.13 \\
Temperate mixed forest & 14845.94 & 36.37 & 10675.52 & 529.92 & 2.01 \\
Temperate broadleaved evergreen forest & 14986.23 & 41.92 & 13002.84 & 460.12 & 0.97 \\
Tropical savanna & 1422.26 & 24.03 & 8006.78 & 401.07 & 1.89 \\
Xeromorphic woodland & 4516.18 & 93.14 & 11121.72 & 949.23 & 2.53 \\
Tropical deciduous forest & 12053.10 & 175.32 & 7844.72 & 943.53 & 1.82 \\
Tropical evergreen forest & 22512.07 & 300.34 & 15059.09 & 900.06 & 0.59 \\
\hline
\end{tabular}

The values are defined from the December pools of the corresponding vegetation-specific calibration. The state variables are defined in Figure 1. All values are in $\mathrm{g} \mathrm{m}^{-2}$. 

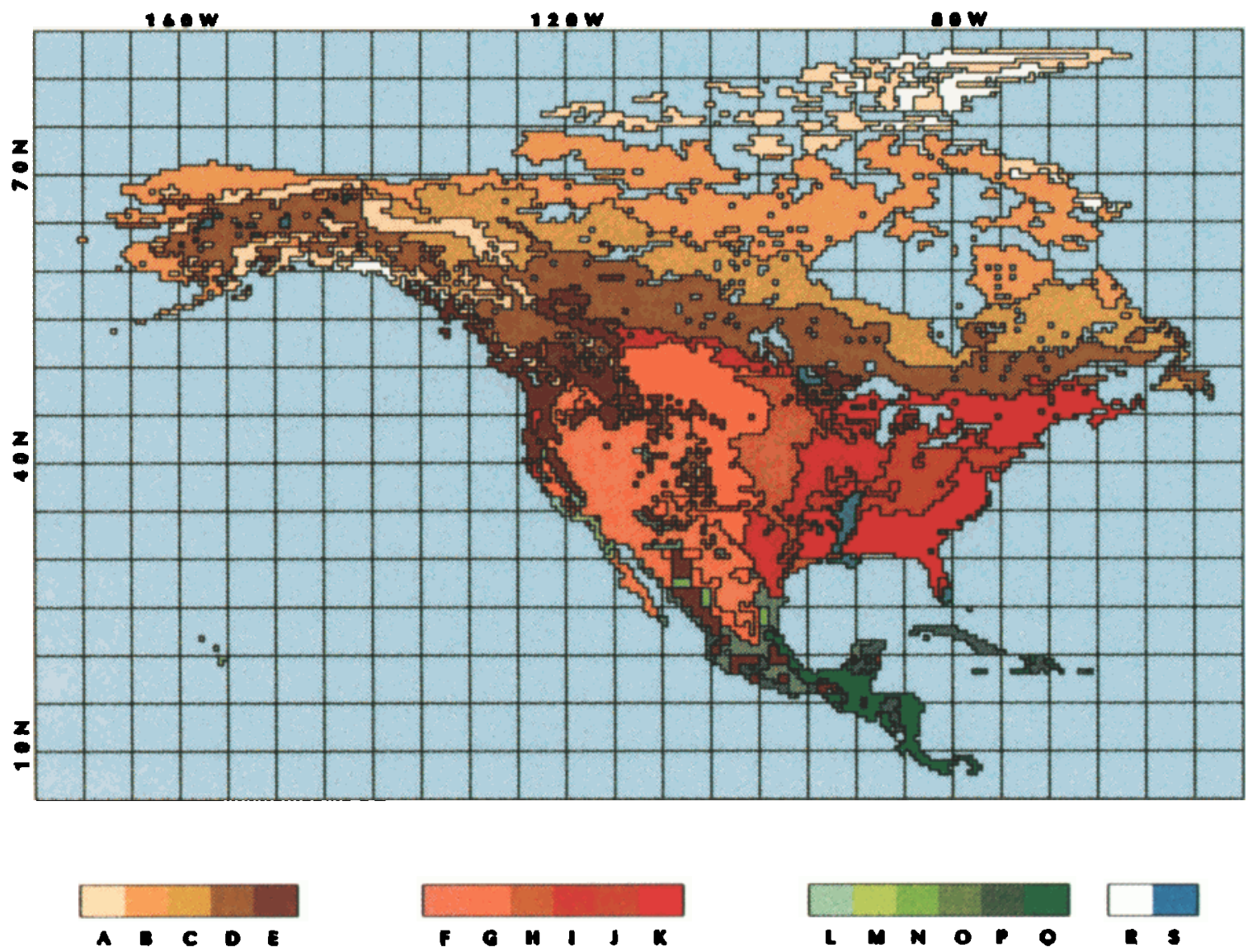

Plate 1. Potential natural vegetation of North America as defined for the terrestrial ecosystem model. The vegetation types are: A, polar desert/alpine tundra; $B$, wet/moist tundra; C, boreal woodland; $D$, boreal forest; E, temperate coniferous forest; F, arid shrubland; G, short grassland; H, tall grassland; I, temperate savanna; $J$, temperate deciduous forest; $\mathrm{K}$, temperate mixed forest; $\mathrm{L}$, temperate broadleaved evergreen forest; $M$, mediterranean shrubland; $N$, tropical savanna; $O$, xeromorphic woodland; $P$, tropical deciduous forest; $Q$, tropical evergreen forest; $R$, ice; and $S$, wetland ecosystems.

of the $\mathrm{C}$ and $\mathrm{N}$ cycles in the response of NPP to an elevated temperature of $2^{\circ} \mathrm{C}$. The $\mathrm{C}$ cycle in TEM can be uncoupled from the $\mathrm{N}$ cycle by not allowing any feedback of $N$ availability on $C$ uptake. This is implemented in the model by setting $f(N A)$ to 1 . The basic design of the experiment is a $2 \times 2$ factorial of nitrogen coupling (uncoupled, coupled) $\mathrm{x}$ temperature change (TEM $\left[+0^{\circ} \mathrm{C}\right]$, TEM $\left.\left[+2^{\circ} \mathrm{C}\right]\right)$. For the response in the uncoupled treatments to be comparable with that of the coupled treatments, we adjusted the parameter $\mathrm{C}_{\max }$ in the uncoupled calibration so that the baseline NPP calculated for the calibration site was identical for both the uncoupled and coupled versions of the model. In the elevated-temperature treatments we increased each monthly temperature for all grid cells by $2^{\circ} \mathrm{C}$.

Increased temperature may affect the response of NPP due to effects of temperature on the metabolism of plant/soil processes. However, soil moisture may also change as a result of increased evapotranspiration.
Therefore the response of NPP may also be due, in part, to the effects of changes in soil moisture on the metabolism of plant/soil processes. We attempted to separate these effects by using the WBM-generated hydrologic inputs for TEM as a third factor (WBM $\left[+0^{\circ} \mathrm{C}\right]$, WBM $\left[+2^{\circ} \mathrm{C}\right]$ ) in the experiment (Table 6 ). In the elevated-temperature scenarios for WBM we increased each monthly temperature for all grid cells by $2^{\circ} \mathrm{C}$.

Plate 2. Annual net primary productivity of potential vegetation in North America as determined by the terrestrial ecosystem model.

Plate 3. Annual net nitrogen mineralization of potential vegetation in North America as determined by the terrestrial ecosystem model. 

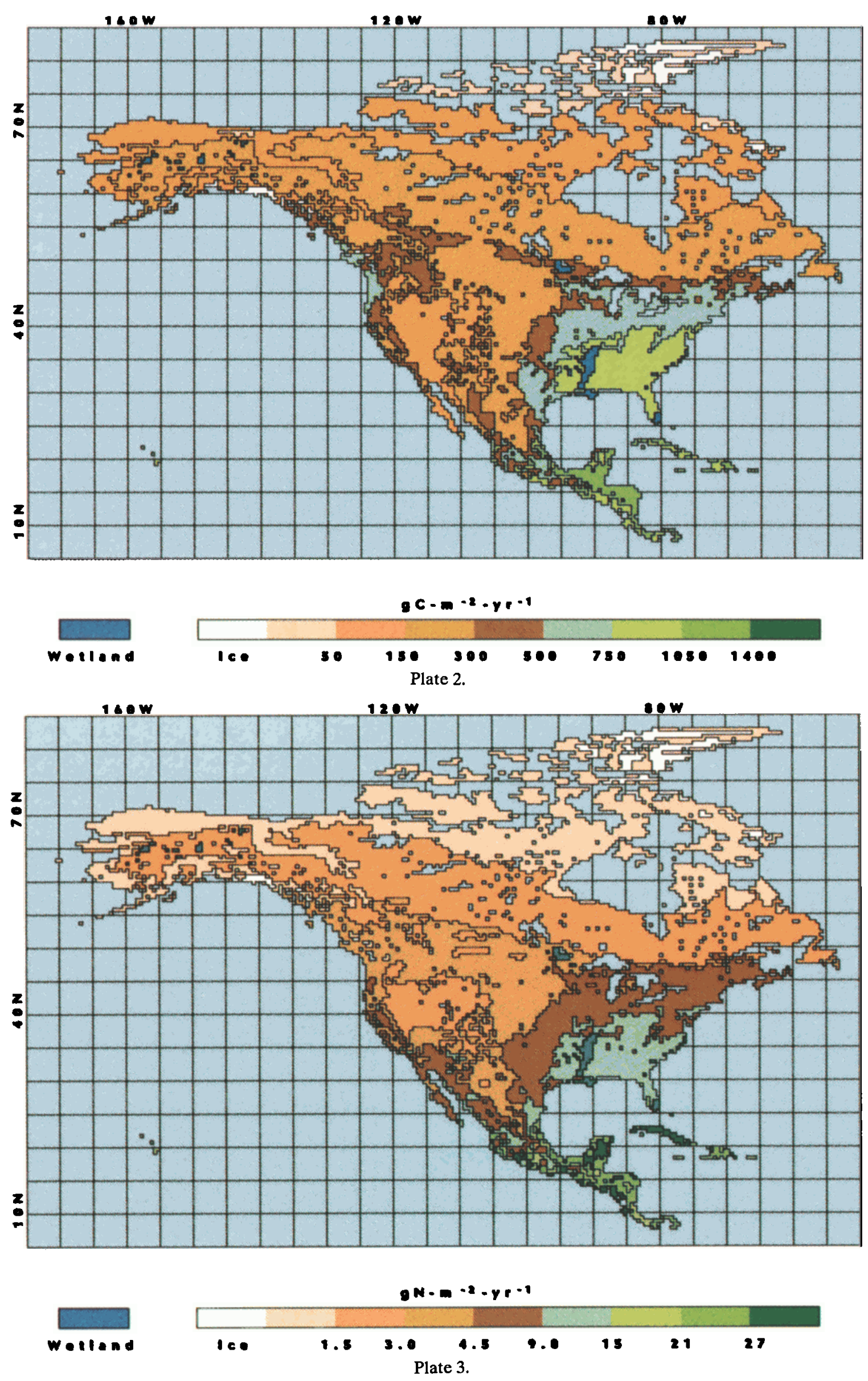
TABLE 6. Design of Experiment on Temperate Mixed Forest in North America to Examine Interactions of the $\mathrm{C}$ and $\mathrm{N}$ Cycles in the Response of NPP to an Elevated Temperature of $2^{\circ} \mathrm{C}$

\begin{tabular}{|c|c|c|c|c|}
\hline & \multicolumn{2}{|c|}{$\begin{array}{l}\text { C Cycle Uncoupled } \\
\text { From the N Cycle }\end{array}$} & \multicolumn{2}{|c|}{$\begin{array}{l}\text { C Cycle Coupled } \\
\text { to the N Cycle }\end{array}$} \\
\hline & $\mathrm{TEM}\left[+0^{\circ} \mathrm{C}\right]$ & $\operatorname{TEM}\left[+2^{\circ} \mathrm{C}\right]$ & $\mathrm{TEM}\left[+0^{\circ} \mathrm{C}\right]$ & $\operatorname{TEM}\left[+2^{\circ} \mathrm{C}\right]$ \\
\hline $\begin{array}{l}\text { WBM } \\
{\left[+0^{\circ} \mathrm{C}\right]}\end{array}$ & $\begin{array}{l}\text { baseline for } \\
\text { uncoupled } \\
\text { response }\end{array}$ & $\begin{array}{l}\text { effects of } \\
\text { temperature } \\
\text { on plant } \\
\text { processes }\end{array}$ & $\begin{array}{l}\text { baseline for } \\
\text { coupled } \\
\text { response }\end{array}$ & $\begin{array}{l}\text { effects of } \\
\text { temperature } \\
\text { on plant and } \\
\text { soil processes }\end{array}$ \\
\hline $\begin{array}{l}\text { WBM } \\
{\left[+2^{\circ} \mathrm{C}\right]}\end{array}$ & $\begin{array}{l}\text { effects of } \\
\text { soil moisture } \\
\text { on plant } \\
\text { processes }\end{array}$ & $\begin{array}{l}\text { effects of } \\
\text { temperature } \\
\text { and soil } \\
\text { moisture on } \\
\text { plant } \\
\text { processes }\end{array}$ & $\begin{array}{l}\text { effects of } \\
\text { soil moisture } \\
\text { on plant and } \\
\text { soil processes }\end{array}$ & $\begin{array}{l}\text { effects of } \\
\text { temperature } \\
\text { and soil } \\
\text { moisture on } \\
\text { plant and } \\
\text { soil processes }\end{array}$ \\
\hline
\end{tabular}

The $\mathrm{C}$ cycle is uncoupled from the $\mathrm{N}$ cycle by not allowing the availability of $\mathrm{N}$ to affect the uptake of $\mathrm{C}$. Mean monthly temperature was increased by $2^{\circ} \mathrm{C}$ for each grid cell when running the terrestrial ecosystem model (TEM) or the water balance model (WBM) for an elevated temperature scenario.

\section{RESULTS}

\section{Annual Net Primary Productivity}

For undisturbed non-wetland vegetation, TEM estimates the annual NPP for North America to be $7.032 \times 10^{15} \mathrm{gC} \mathrm{yr}^{-1}$, or $338.7 \mathrm{gC} \mathrm{m}^{-2} \mathrm{yr}^{-1}$ (Table 7). Among all ecosystems, temperate mixed forest accounts for the greatest exchange of $\mathrm{CO}_{2}$ with the atmosphere in
North America (18.8\%, Table 7). Mean NPP estimates for ecosystems range from $69.5 \mathrm{gC} \mathrm{m}^{-2} \mathrm{yr}^{-1}$ for polar desert of northern Canada to $1113.0 \mathrm{gC} \mathrm{m}^{-2} \mathrm{yr}^{-1}$ for tropical evergreen forest of Central America. Estimates for individual grid cells range from $31.3 \mathrm{gC} \mathrm{m}^{-2} \mathrm{yr}^{-1}$ in polar desert to $1489.4 \mathrm{gC} \mathrm{m}^{-2} \mathrm{yr}^{-1}$ in tropical deciduous forest (Table 7, Plate 2).

Polar desert, moist tundra, boreal woodland, boreal

TABLE 7. Estimates by the Terrestrial Ecosystem Model of Annual Net Primary Productivity (NPP) for Potential Vegetation in North America

\begin{tabular}{lccccc}
\hline \multicolumn{1}{c}{ Vegetation Type } & $\begin{array}{c}\text { Area, } \\
10^{6} \mathrm{~km}^{2}\end{array}$ & Cells & $\begin{array}{r}\text { Total NPP, } \\
10^{15} \mathrm{gC} \mathrm{yr}^{-1}\end{array}$ & $\begin{array}{c}\text { Max NPP, } \\
\mathrm{gC} \mathrm{m}^{-2} \mathrm{yr}^{-1}\end{array}$ & $\begin{array}{r}\text { Min NPP, } \\
\mathrm{gC} \mathrm{m}^{-2} \mathrm{yr}^{-1}\end{array}$ \\
\hline Polar desert/alpine tundra & 1.11 & 1060 & 0.077 & 124.9 & 31.3 \\
Wet/moist tundra & 2.54 & 2093 & 0.246 & 169.3 & 56.6 \\
Boreal woodland & 2.18 & 1387 & 0.415 & 257.5 & 94.7 \\
Boreal forest & 3.43 & 1991 & 0.789 & 358.5 & 116.8 \\
Temperate coniferous forest & 1.51 & 693 & 0.596 & 684.0 & 185.7 \\
Arid shrubland & 2.01 & 810 & 0.267 & 265.2 & 53.4 \\
Short grassland & 1.60 & 706 & 0.334 & 398.2 & 131.6 \\
Tall grassland & 0.77 & 329 & 0.252 & 723.3 & 201.8 \\
Temperate savanna & 1.09 & 464 & 0.564 & 946.8 & 278.0 \\
Temperate mixed forest & 1.80 & 757 & 1.323 & 1020.1 & 380.7 \\
Temperate deciduous forest & 0.90 & 376 & 0.659 & 948.6 & 408.6 \\
Temperate broadleaved evergreen forest & 0.05 & 19 & 0.022 & 915.2 & 289.2 \\
Mediterranean shrubland & 0.06 & 24 & 0.021 & 429.1 & 212.0 \\
Tropical savanna & 0.11 & 40 & 0.046 & 827.3 & 212.0 \\
Xeromorphic forest & 0.48 & 169 & 0.212 & 722.8 & 150.4 \\
Tropical deciduous forest & 0.46 & 159 & 0.472 & 1489.4 & 639.0 \\
Tropical evergreen forest & 0.66 & 222 & 0.737 & 1413.5 & 716.5 \\
& & & & & 31.3 \\
Total & 20.76 & 11,299 & 7.032 & 1489.4 & 3 \\
\hline
\end{tabular}




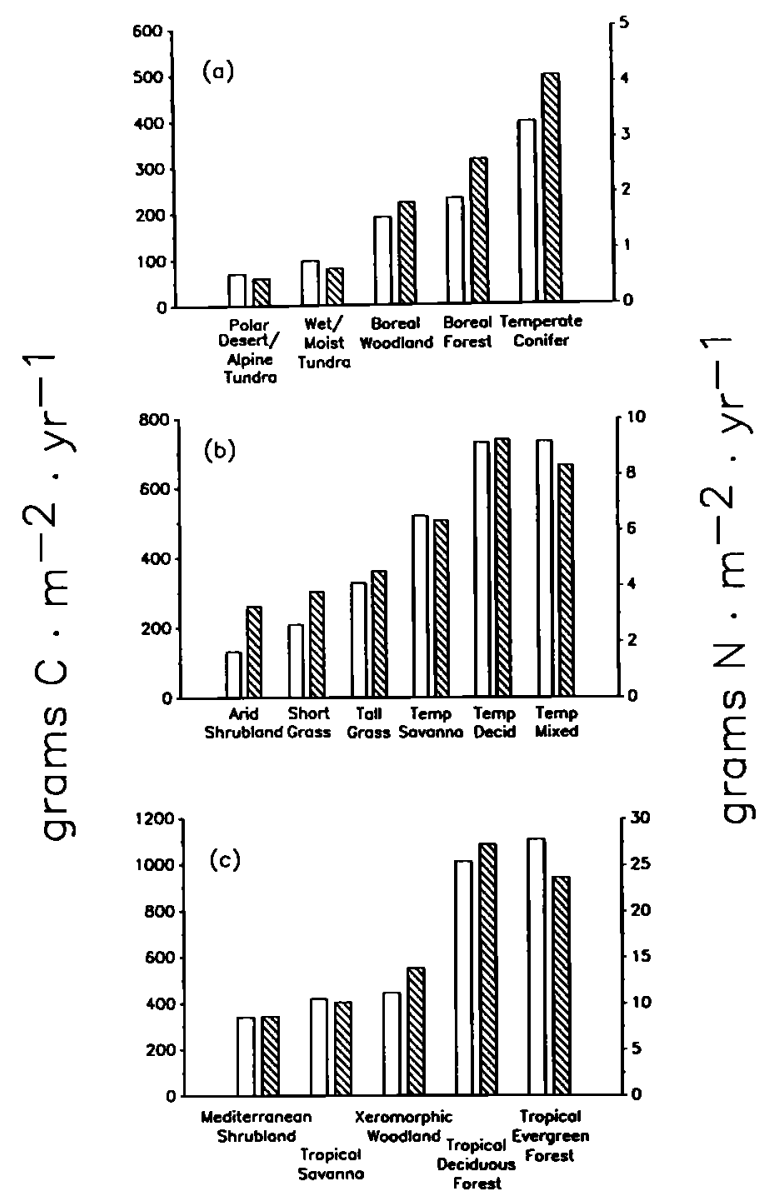

Fig. 3. Mean annual net primary productivity (blank bars) and net nitrogen mineralization (diagonally lined bars) as determined by the terrestrial ecosystem model for ecosystems generally occurring along a north to south gradient in (a) northern North America, generally occurring along a west to east gradient in (b) temperate North America, and in (c) the tropics and subtropics.

forest, and coniferous forest generally occur sequentially from north to south in northern North America (Plate 1). Estimates of mean annual NPP increase across this ecosystem gradient (Figure $3 \mathrm{a}$ ). Mean annual temperature and NPP generally increase along a north-south transect in western Canada that spans this ecosystem gradient (Figure 4a). However, as the transect crosses the Canadian Rockies, NPP changes rapidly because the vegetation is very heterogeneous (temperate coniferous forest, boreal forest, and alpine tundra). Mean annual temperature is probably overestimated in this region because of the lack of meteorological stations at the higher elevations. The simulated NPP in this area is lower than would be expected on the basis of the temperature data because $C$ and $\mathbf{N}$ dynamics in TEM are constrained by the parameters associated with boreal forest and alpine tundra.
Arid shrublands, short grassland, tall grassland, temperate savanna, and temperate deciduous and mixed forests generally occur sequentially from west to east in temperate North America (Plate 1). Estimates of mean annual NPP increase along this ecosystem gradient (Figure 3b). Both annual precipitation and mean annual NPP increase along a west-east transect that travels through this ecosystem gradient (Figure $4 \mathrm{~b}$ ). In the transition zone between tall grassland and temperate savanna, NPP changes rapidly because the vegetation is switching back and forth between the two ecosystem types. In the tropics and subtropics, TEM predicts that forested ecosystems are more productive than non-forested ecosystems (Figure 3c).

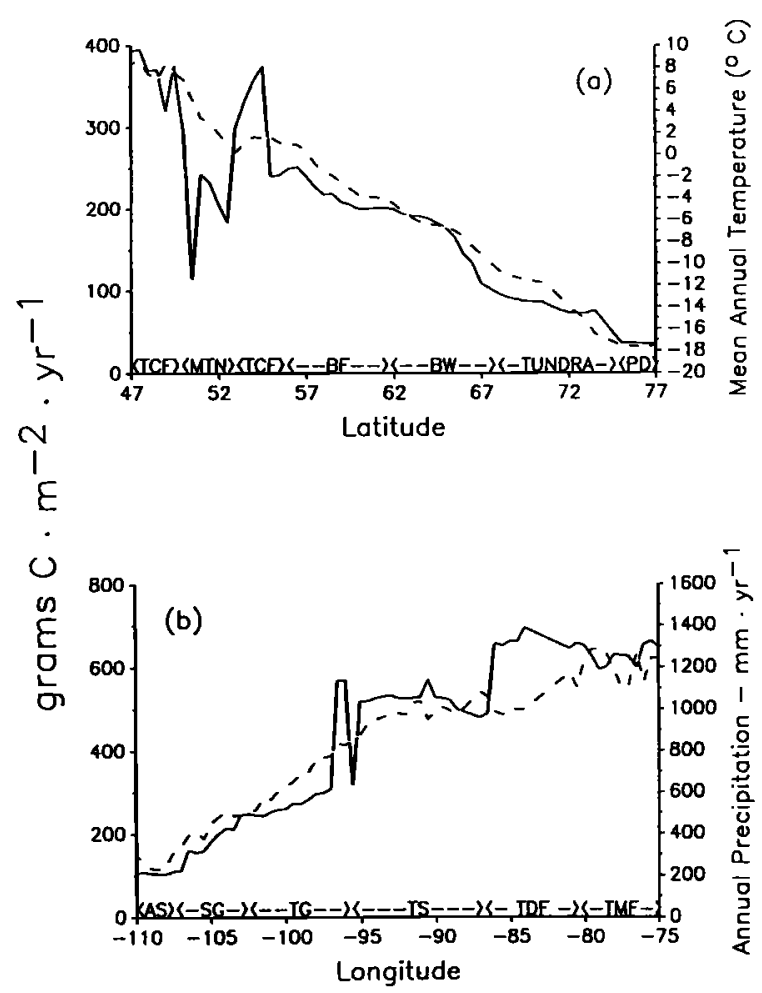

Fig. 4. Mean annual net primary productivity (solid lines) as determined by the terrestrial ecosystem model for a (a) temperature gradient along longitude $117^{\circ} \mathrm{W}$ between latitudes $47^{\circ} \mathrm{N}$ and $77^{\circ} \mathrm{N}$ and a (b) moisture gradient along latitude $41.5^{\circ} \mathrm{N}$ between longitudes $110^{\circ}$ $\mathrm{W}$ and $75^{\circ} \mathrm{W}$. Dashed lines indicate mean annual temperature in Figure $4 a$ and annual precipitation in Figure 4b. Abbreviations: TCF, temperate coniferous forest; MTN, mountainous region; BF, boreal forest; BW, boreal woodland; TUNDRA, wet/moist tundra; PD, polar desert; AS, arid shrubland; SG, short grassland; TG, tall grassland; TS, temperate savanna; TDF, temperate deciduous forest; and TMF, temperate mixed forest. 
TABLE 8. Estimates by the Terrestrial Ecosystem Model of Annual Net N mineralization (NETNMIN) for Potential Vegetation in North America

\begin{tabular}{|c|c|c|c|c|c|}
\hline Vegetation Type & $\begin{array}{c}\text { Area, } \\
10^{6} \mathrm{~km}^{2}\end{array}$ & Cells & $\begin{array}{c}\text { Total } \\
\text { NETNMIN, } \\
10^{12} \text { gN yr }^{-1}\end{array}$ & $\begin{array}{c}\text { Max } \\
\text { NETNMIN, } \\
\text { gN m }^{-2} \text { yr }^{-1}\end{array}$ & $\begin{array}{c}\text { Min } \\
\text { NETNMIN, } \\
\text { gN m }^{-2} \mathrm{yr}^{-1}\end{array}$ \\
\hline Polar desert/alpine tundra & 1.11 & 1060 & 0.5 & 1.96 & 0.15 \\
\hline Wet/moist tundra & 2.54 & 2093 & 1.7 & 1.43 & 0.30 \\
\hline Boreal woodland & 2.18 & 1387 & 4.0 & 2.68 & 0.92 \\
\hline Boreal forest & 3.43 & 1991 & 9.0 & 4.76 & 1.61 \\
\hline Temperate coniferous forest & 1.51 & 693 & 6.2 & 11.26 & 2.14 \\
\hline Arid shrubland & 2.01 & 810 & 6.6 & 6.51 & 1.53 \\
\hline Short grassland & 1.60 & 706 & 6.1 & 6.56 & 2.47 \\
\hline Tall grassland & 0.77 & 329 & 3.5 & 9.30 & 2.85 \\
\hline Temperate savanna & 1.09 & 464 & 6.9 & 10.60 & 3.33 \\
\hline Temperate mixed forest & 1.80 & 757 & 15.0 & 15.71 & 4.58 \\
\hline Temperate deciduous forest & 0.90 & 376 & 8.3 & 13.54 & 5.78 \\
\hline Temperate broadleaved evergreen forest & 0.05 & 19 & 0.2 & 9.58 & 4.36 \\
\hline Mediterranean shrubland & 0.06 & 24 & 0.5 & 10.46 & 7.53 \\
\hline Tropical savanna & 0.11 & 40 & 1.1 & 18.14 & 6.93 \\
\hline Xeromorphic forest & 0.48 & 169 & 6.6 & 24.38 & 5.39 \\
\hline Tropical deciduous forest & 0.46 & 159 & 12.7 & 35.48 & 15.72 \\
\hline Tropical evergreen forest & 0.66 & 222 & 15.7 & 31.56 & 15.93 \\
\hline Total & 20.76 & 11,299 & 104.6 & 35.48 & 0.15 \\
\hline
\end{tabular}

\section{Annual Net Nitrogen Mineralization}

For undisturbed non-wetland vegetation, TEM estimates the mean annual net nitrogen mineralization (NETNMIN) of North America to be $104.6 \times 10^{12} \mathrm{gN}$ $\mathrm{yr}^{-1}$, or $5.04 \mathrm{gN} \mathrm{m}^{-2} \mathrm{yr}^{-1}$ (Table 8). Mean NETNMIN estimates for ecosystems range from $0.50 \mathrm{gN} \mathrm{m}^{-2} \mathrm{yr}^{-1}$ in polar desert to $27.29 \mathrm{gN} \mathrm{m}^{-2} \mathrm{yr}^{-1}$ in tropical deciduous forest. Estimates for individual grid cells range from $0.150 \mathrm{gN} \mathrm{m}^{-2} \mathrm{yr}^{-1}$ in polar desert to $35.48 \mathrm{gN} \mathrm{m}^{-2} \mathrm{yr}^{-1}$ in tropical deciduous forest (Table 8, Plate 3). Ranges within ecosystems are comparable to those reported by Nadelhoffer et al. [1991] (Figure 5).

In northern ecosystems, mean annual NETNMIN increases along a gradient from polar desert to temperate coniferous forest (Figure 3a). Similarly, in temperate North America NETNMIN increases along a gradient from arid shrubland to temperate deciduous and mixed forests (Figure $3 b$ ). In the tropics and subtropics, estimates of NETNMIN are higher for forested than for non-forested ecosystems (Figure 3c).

\section{Limitation of Productivity by Nitrogen Availability}

When the availability of $\mathbf{N}$ does not restrict the uptake of $\mathrm{C}$ by the vegetation (i.e., the $\mathrm{C}$ cycle is uncoupled from the $\mathrm{N}$ cycle), the estimate of mean annual NPP for North America is $448.9 \mathrm{gC} \mathrm{m}^{-2} \mathrm{yr}^{-1}$. This suggests that productivity could be $32.5 \%$ higher if $\mathrm{N}$ is not limiting. The strength of $\mathbf{N}$ limitation differs regionally in North America (Figure 6). It is very weak in forests of the tropical region, increasingly stronger in forests of the temperate and boreal regions, and strongest in tundra ecosystems. In tundra ecosystems, NPP in the N-limited scenario is on average about $50 \%$ of that predicted when there is no $\mathrm{N}$ limitation. The degree to which productivity is limited by the availability of $\mathrm{N}$ also varies within ecosystems (Figure 6). Along a transect from south to north through arctic ecosystems in western Canada, productivity initially becomes more limited by $\mathrm{N}$ availability and then becomes less limited (Figure 7). In the northern portion of this transect the decrease in the strength of $\mathrm{N}$ limitation may be the

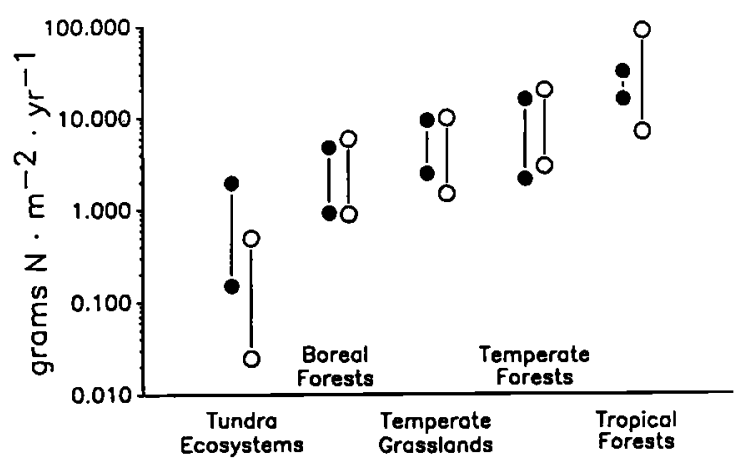

Fig. 5. Comparison between the ranges of annual net nitrogen mineralization predicted by the terrestrial ecosystem model (filled circles) and those reported by Nadelhoffer et al. [1991] (open circles) for tundra and grassland ecosystems, and forests of the boreal, temperate, and tropical regions. 


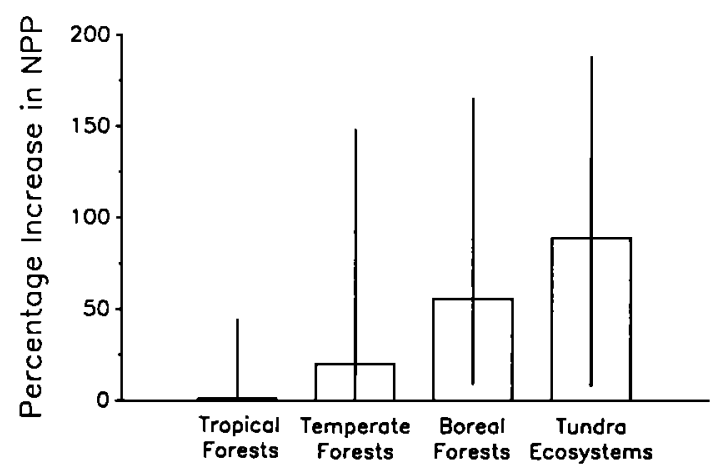

Fig. 6. Predicted effect on regional net primary productivity of eliminating limitation due to nitrogen availability. Percentage increase in NPP (mean and range) is shown for tundra ecosystems and for forests in the tropical, temperate, and boreal regions.

result of photosynthetic processes becoming increasingly more affected by lower temperatures than by $\mathrm{N}$ availability. Thus the tightness of the coupling between the $\mathrm{C}$ and $\mathrm{N}$ cycles may change within ecosystems due to interactions with other factors.

\section{Experiment Examining the Interactions of $C$ and $N$ in the Response of NPP to Elevated Temperature}

When TEM is run with the $\mathrm{C}$ cycle coupled to the $\mathrm{N}$ cycle, the estimate of mean annual NPP for temperate mixed forest in North America is $735.6 \mathrm{gC} \mathrm{m}^{-2} \mathrm{yr}^{-1}$ (Table 7). The estimate for the $\mathrm{C}$ cycle calibrated and run uncoupled from the $\mathrm{N}$ cycle is within $10 \%$ of this value. We use these estimates as the baseline values for comparing the response of NPP of temperate mixed forest to an elevated temperature of $2^{\circ} \mathrm{C}$ (Table 6 ).

When the temperature is elevated by $2^{\circ}$ for WBM, but not for TEM, NPP of temperate mixed forest does not respond if $\mathrm{N}$ cycling is uncoupled (Figure 8). In the case of coupled $\mathrm{C}$ and $\mathrm{N}$ cycling the negative response of

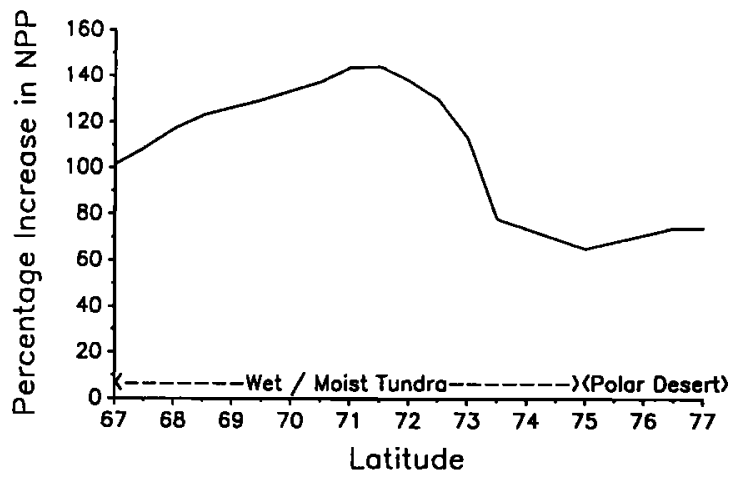

Fig. 7. Predicted effect on net primary productivity in the arctic of eliminating limitation due to nitrogen availability. Percentage increase in NPP is shown for a transect at $117^{\circ} \mathrm{W}$.

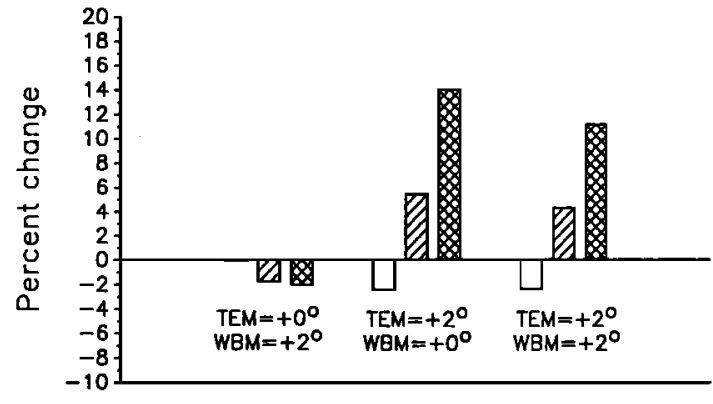

Fig. 8. Response of net primary productivity (NPP) and net nitrogen mineralization (NETNMIN) for temperate mixed forests of North America in an elevatedtemperature experiment. Monthly temperature was increased $2^{\circ}$ for the terrestrial ecosystem model (TEM) or the water balance model (WBM), which provides climatic inputs to TEM. Blank and diagonally-lined bars correspond to the NPP response when TEM was run with the carbon cycle uncoupled or coupled to the nitrogen cycle, respectively. The crosshatched bar is the NETNMIN response with the carbon cycle coupled to the nitrogen cycle.

NPP is similar to the decrease in NETNMIN. These results suggest that lower soil moisture affected NPP more strongly through $\mathrm{N}$ availability than through lower leaf conductivity to $\mathrm{CO}_{2}$.

When temperature is elevated by $2^{\circ}$ for TEM, but not for WBM, NPP of temperate mixed forest responds negatively if $\mathrm{N}$ cycling is not considered (Figure 8 ) but positively in the case of coupled $\mathrm{C}$ and $\mathrm{N}$ cycling. Because the positive response is much greater than the negative response, these results suggest that NPP is more affected by elevated $\mathrm{N}$ availability than by increased plant respiration.

When temperature is elevated by $2^{\circ}$ for both TEM and WBM, the NPP response is essentially the additive results of the two previous treatments (Figure 8 ). The net result is that NPP responds negatively for the $C$ cycle uncoupled from the $\mathrm{N}$ cycle, but positively in the case of coupled $\mathrm{C}$ and $\mathrm{N}$ cycling. Again, the positive response is greater than the negative response. This suggests that NPP is more affected by increased N availability because of higher mineralization rates than by higher plant respiration or lower leaf conductivity to $\mathrm{CO}_{2}$.

The parameter $P_{c n}$, which is the ratio of NPP to N requirement for the calibration site, is a measure of the efficiency of $\mathbf{N}$ use by the vegetation. To investigate the sensitivity of the net result of the experiment to this parameter, we used $\mathbf{N}$ requirement and associated organic matter increment from the woodlands data set of Cole and Rapp [1981] to define $P_{\mathrm{cn}}$ for 13 temperate coniferous and 14 temperate deciduous forest stands. The calculated values of $P_{c n}$ range from 34.19 to 109.11 , with temperate deciduous and temperate coniferous forest stands occupying the lower and upper ends of the distribution, respectively. We developed two additional 
calibrations for temperate mixed forest using the low and high values of $P_{c n}$ in this distribution and ran the model with each of these calibrations for both the baseline treatment and the treatment with temperature elevated $2^{\circ} \mathrm{C}$ for both TEM and WBM. In our experiments with temperate mixed forest the ranges in response of NPP and NETNMIN to elevating temperature by $2^{\circ}$ are 2.3 to $4.0 \%$ and 9.0 to $13.2 \%$, respectively. Thus the net responses of NPP and NETNMIN in the experiment are robust to our original definition of $\mathbf{P}_{\mathrm{cn}}$ for temperate mixed forest. The results of this experiment indicate that the coupling of the $\mathrm{N}$ cycle to the $\mathrm{C}$ cycle is important to consider in predicting the response of NPP to elevated temperature.

\section{DISCUSSION}

\section{Importance of $C$ and $N$ Interactions in Estimating NPP}

It has long been recognized that the spatial pattern of NPP at continental to global scales can be explained by spatial patterns in temperature and moisture [Lieth, 1973, 1975]. For the northern region of North America, NPP estimates of the Miami model of Lieth [1975] generally increase from north to south, a pattern primarily representing that generated by the temperature submodel of the Miami model. Similarly, in temperate North America, NPP estimates of the Miami model generally increase west to east; this pattern primarily represents that generated by the precipitation submodel. The Century model [Parton et al., 1987] also predicts NPP to increase west to east across the Great Plains in the United States, a pattern that correlates with increasing precipitation. The spatial patterns of NPP generated by TEM in northern and temperate North America agree qualitatively with the patterns generated by the Miami and Century models.

In northern and temperate regions of North America, estimated patterns of productivity by TEM mirror those of NETNMIN. This occurs because the availability of inorganic $\mathrm{N}$ limits productivity in the ecosystems of those regions. Thus the exchange of $\mathrm{CO}_{2}$ between much of the terrestrial biosphere and the atmosphere is coupled to the $\mathrm{N}$ cycle. The models developed by Lieth [1975] and his coworkers implicitly rely on the correlation between mineralization rates and environmental factors to predict NPP. However, as we have shown, the degree to which the availability of $\mathbf{N}$ limits productivity can vary substantially within ecosystems. Thus models that explicitly incorporate the effect of the $\mathbf{N}$ cycle on plant productivity should be capable of better spatial resolution in estimating the exchanges of $\mathrm{C}$ between the atmosphere and the terrestrial biosphere.

\section{Importance of $C$ and $N$ Interactions in Predicting the Response of NPP to Elevated Temperature}

Because productivity of much of the terrestrial biosphere is limited by the availability of $\mathrm{N}$, determining how global change will affect productivity requires understanding how it will affect the interaction between the $\mathrm{C}$ and $\mathrm{N}$ cycles. In our elevated-temperature experiment the response of NPP is very different depending on whether or not $\mathrm{N}$ cycling is considered. Thus, to investigate how global change will affect biosphere-atmosphere interactions, process-based models need to incorporate linkages between the $C$ and $\mathrm{N}$ cycles.

We did not intend to use our elevated-temperature experiments to define the NPP response of temperate mixed forest to global change. Changes in $\mathrm{CO}_{2}$, precipitation, nutrient deposition, and land use may be substantial in temperate regions, and these were not considered in our experiment. However, our results may have implications for arctic and boreal ecosystems where annual temperature increases of between $5^{\circ}$ and $10^{\circ} \mathrm{C}$ are expected to occur sometime during the next century [Mitchell et al., 1990]. These ecosystems contain substantial amounts of organic $\mathrm{C}$ and $\mathrm{N}$ in their soils that could be released in inorganic forms in response to elevated temperature [Nadelhoffer et al., 1991]. A large release of $\mathrm{CO}_{2}$ from these systems has the potential to increase the $\mathrm{CO}_{2}$ concentration of the atmosphere. However, increased $\mathrm{N}$ availability associated with elevated temperature should result in increased NPP. This response has the potential to buffer the carbon loss from the soil.

In our experiments the increased NPP in response to elevated temperature indicates that such buffering could occur. Rastetter et al. [1991] report a similar result in elevated-temperature experiments with a general biogeochemical model (MBLGEM). The degree of buffering will depend on the fate of the "newly available" $\mathbf{N}$ that has resulted from warming. Increased decomposition of soil organic matter because of warming will result in the release of $\mathrm{C}$ as $\mathrm{CO}_{2}$ to the atmosphere and an increase in the size of the soil inorganic $\mathrm{N}$ pool. If much of the $\mathrm{N}$ is taken up by the vegetation, the entire ecosystem will function as a net carbon sink because the vegetation has a much higher $\mathrm{C}$ to $\mathrm{N}$ ratio than soil. Alternatively, if "newly available" $\mathrm{N}$ is lost from the ecosystem, then the ecosystem will function as a net carbon source.

\section{Future Application of TEM Results to Trace Gas Modeling}

Our results on NETNMIN are the first reported estimates of $\mathbf{N}$ cycling at continental to global scales. Explicitly modeling the $\mathbf{N}$ cycle in a spatially defined manner will be important to investigating the interaction of the terrestrial biosphere with trace gases such as methane and nitrous oxide. Although other factors besides $\mathrm{N}$ are important in controlling the exchange of these gases [Conrad, 1989; Galbally, 1989], a link does exist between NETNMIN and both the uptake of methane [Steudler et al., 1989; Mosier et al., 1991; Steudler et al., 1992] and the production of nitrous oxide [Melillo et al., 1983; Matson and Vitousek, 1987; Bowden et al., 1991; Steudler et al., 1992]. The dynamics of these gases are spatially and seasonally variable 
[Matson et al., 1989]. The ability of TEM to make estimates of NETNMIN that are spatially and temporally resolved is an important development in our efforts to investigate the net exchange of these gases with the terrestrial biosphere.

\section{Recommendations for Ecosystem-Level Studies}

Significant improvements in the calibration of TEM include the use of information on $\mathbf{N}$ recycling and $\mathbf{N}$ fertilization. These enhancements have advanced our ability to model the linkage between the $\mathrm{C}$ and $\mathrm{N}$ cycles. Information on $\mathrm{N}$ recycling, in part, is used to define carbon-nitrogen balance for an ecosystem. Data on the maximum response of NPP to N fertilization are used during calibration to define the maximum rate of carbon assimilation, a procedure that implicitly constrains leaf area. Better data on N recycling and the NPP response to $\mathrm{N}$ fertilization in ecosystem-level studies would certainly improve our calibration of TEM. They would also aid in developing new versions of the model to more explicitly model the allocation of resources to $\mathrm{C}$ versus $\mathbf{N}$ uptake.

An improvement in the calibration of the $\mathrm{C}$ cycle is the ability to estimate GPP for the calibration site in a spatially explicit fashion. This improvement, we believe, results in better spatial resolution in the estimates of plant respiration by TEM. However, our estimates of GPP could be greatly improved if ecosystem-level studies consistently measured several quantities [see Ryan, 1991a]: aboveground wood production, aboveground leaf production, belowground NPP, $C$ in sapwood, $\mathrm{C}$ in heartwood, organic $\mathrm{N}$ in foliage, organic $\mathrm{N}$ in sapwood, and organic $\mathrm{N}$ in heartwood.

The availability of inorganic phosphorous is known to be low in soils of tropical [Jones and Wild, 1975; Sanchez et al., 1982] and arctic [Chapin et al., 1980; Shaver et al., 1990; Giblin et al., 1991; Nadelhoffer et al., 1991] ecosystems. As discussed by Raich et al. [1991], the omission of phosphorous is partially overcome by the calibration of the model to correctly predict NPP on phosphorous-deficient soils. However, this procedure assumes that phosphorous either does or does not limit NPP over the entire ecosystem. Therefore the inclusion of the effects of phosphorous into TEM would improve the spatial resolution of model predictions. Unfortunately, compared to the $\mathrm{N}$ cycle, the phosphorous cycle has been much less studied. Measurement in ecosystem-level studies of the saturation response of NPP to phosphorous fertilization, recycling rates of phosphorous in vegetation, and NPP response in factorial studies of phosphorous and nitrogen fertilization would greatly improve our ability to incorporate phosphorous into our modeling efforts.

\section{Conclusion}

Other models have been developed to examine exchanges of $\mathrm{CO}_{2}$ between the atmosphere and the terrestrial biosphere [Houghton et al., 1983; Emanuel et al., 1984; Gillette and Box, 1986; Esser, 1987; Fung et al., 1987; King et al., 1989]. The TEM model is unique among these models because it incorporates feedbacks between the $\mathrm{C}$ and $\mathrm{N}$ cycles in estimating the exchange of $\mathrm{CO}_{2}$. The most significant improvement in TEM is the design of a new feedback algorithm between $\mathrm{C}$ and $\mathrm{N}$ uptake. The algorithm was designed so that information from field studies on $\mathrm{N}$ recycling and the NPP response to $\mathrm{N}$ fertilization can be used to calibrate the linkage between $\mathrm{C}$ and $\mathrm{N}$ dynamics. Because nitrogen limitation of productivity can vary substantially within ecosystems, modeling the linkage between $C$ and $\mathrm{N}$ dynamics improves spatial resolution in estimating exchanges of $\mathrm{CO}_{2}$ between the atmosphere and the terrestrial biosphere. Also, the linkage between $\mathrm{C}$ and $\mathrm{N}$ dynamics is essential to consider in estimating the response of terrestrial ecosystems to elevated temperature. The evaluation in this study of the linkage between $\mathrm{C}$ and $\mathrm{N}$ dynamics in estimating NPP is a step forward in our goal of applying TEM to investigate the response of the terrestrial biosphere to global change, that is, changes in climate, environmental chemistry, and land use.

\section{APPENDIX}

Data used to calibrate the terrestrial ecosystem model for each vegetation type are described in the 16 tables of this appendix. Mean annual values of carbon in vegetation $\left(C_{V}\right)$, nitrogen in vegetation $\left(N_{V}\right)$, carbon in soil $\left(\mathrm{C}_{\mathrm{S}}\right)$, nitrogen in soil $\left(\mathrm{N}_{\mathrm{S}}\right)$, and inorganic nitrogen in soil $\left(\mathrm{N}_{\mathrm{AV}}\right)$ are in $\mathbf{g ~ m}^{-2}$ of either carbon or nitrogen. Values of gross primary productivity (GPP), net primary productivity (NPP), nitrogen uptake by vegetation (NUPTAKE), saturation response of NPP to nitrogen fertilization (NPPSAT), and the annual amount of nitrogen mobilized for production via recycling (NMOBIL) are in $\mathrm{g} \mathrm{m}^{-2} \mathrm{yr}^{-1}$. We assume that NPP = carbon in litter production = carbon in heterotrophic respiration and that NUPTAKE $=$ nitrogen in litter production = net nitrogen mineralization (NETNMIN) during calibration of the model. 
TABLE A1. Polar Desert/Alpine Tundra: Toolik Lake, Alaska

\begin{tabular}{|c|c|c|}
\hline Variable & Value & Source and Comments \\
\hline $\mathrm{C}_{\mathrm{V}}$ & 450 & based on Table 11 by Shaver and Chapin [1991]. \\
\hline $\mathrm{N}_{\mathrm{V}}$ & 6.5 & based on Table 5 by Shaver and Chapin [1991]. \\
\hline $\mathrm{C}_{\mathrm{S}}$ & 6000 & based on Tables 4 and 5 by Giblin et al. [1991]. \\
\hline $\mathrm{N}_{\mathbf{S}}$ & 260 & based on Tables 4 and 5 by Giblin et al. [1991]. \\
\hline $\mathrm{N}_{\mathrm{AV}}$ & 0.4 & estimated. \\
\hline GPP & 255 & based on respiration budgets of Chapin et al. [1980]. \\
\hline NPP & 65 & based on Table 11 by Shaver and Chapin [1991]. \\
\hline NPPSAT & 130 & based on evergreens at Toolik in Table 2 of Shaver and Chapin [1986]. \\
\hline NUPTAKE & 0.5 & NETNMIN in Table 5.2 of Shaver et al. [1990]. \\
\hline NMOBIL & 1.3 & $\begin{array}{l}\text { based on } 75 \% \text { recycling (values for evergreen leaves range from } 60 \text { to } 80 \% \text { in Table } 9 \text { of } \\
\text { Shaver and Chapin [1991]). }\end{array}$ \\
\hline
\end{tabular}

Data are based on vegetation in the heath site.

TABLE A2. Wet/Moist Tundra: Toolik Lake, Alaska

\begin{tabular}{|c|c|c|}
\hline Variable & Value & Source and Comments \\
\hline $\mathrm{C}_{\mathrm{V}}$ & 750 & based on Table 11 by Shaver and Chapin [1991]. \\
\hline $\mathrm{N}_{\mathbf{V}}$ & 15 & based on Table 5 by Shaver and Chapin [1991]. \\
\hline $\mathrm{C}_{\mathrm{S}}$ & 18000 & based on Tables 4 and 5 by Giblin et al. [1991]. \\
\hline $\mathrm{N}_{\mathbf{S}}$ & 1100 & based on Tables 4 and 5 by Giblin et al. [1991]. \\
\hline $\mathrm{N}_{\mathrm{AV}}$ & 0.4 & estimated. \\
\hline GPP & 440 & based on respiration budgets of Chapin et al. [1980]. \\
\hline NPP & 120 & based on Table 11 by Shaver and Chapin [1991]. \\
\hline NPPSAT & 225 & based on Table 2 by Shaver and Chapin [1986]. \\
\hline NUPTAKE & 0.8 & $\begin{array}{l}\text { based on Table } 5 \text { by Shaver and Chapin [1991] and } 80 \% \text { recycling (values for tundra } \\
\text { leaves range from } 50 \text { to } 80 \% \text { in Table } 9 \text { of Shaver and Chapin [1991]). }\end{array}$ \\
\hline NMOBIL & 3.2 & based on Table 5 by Shaver and Chapin [1991] and $80 \%$ recycling. \\
\hline
\end{tabular}

Assumes that vegetation typical of the tussock site, wet site, heath site, and shrub site covers $40 \%, 40 \%$, $15 \%$, and $5 \%$ of the landscape, respectively.

TABLE A3. Boreal Woodland: Schefferville, Quebec, Canada

\begin{tabular}{|c|c|c|}
\hline Variable & Value & Source and Comments \\
\hline $\mathrm{C}_{\mathrm{V}}$ & 2200 & based on Tables 5 and 7 by Auclair and Rencz [1982]. \\
\hline $\mathrm{N}_{\mathrm{V}}$ & 24 & based on Table 5 by Auclair and Rencz [1982]. \\
\hline $\mathrm{C}_{\mathrm{s}}$ & 13350 & based on tundra and boreal forest calibrations. \\
\hline $\mathrm{N}_{\mathrm{S}}$ & 735 & based on tundra and boreal forest calibrations. \\
\hline $\mathrm{N}_{\mathrm{AV}}$ & 0.5 & based on tundra and boreal forest calibrations. \\
\hline GPP & 456 & based on tundra and boreal forest calibrations. \\
\hline NPP & 170 & based on tundra and boreal forest calibrations. \\
\hline NPPSAT & 265 & based on tundra and boreal forest calibrations. \\
\hline NUPTAKE & 1.5 & based on tundra and boreal forest calibrations. \\
\hline NMOBIL & 2.6 & based on tundra and boreal forest calibrations. \\
\hline
\end{tabular}

Assumes that vegetation typical of tundra and forest covers $50 \%$ of the landscape, respectively. Results from running the calibrations for wet/moist tundra and boreal forest on the Schefferville grid cell were used to estimate some of the values for this site. 
TABLE A4. Boreal Forest: Bonanza Creek Experimental Forest, Alaska

\begin{tabular}{|c|c|c|}
\hline Variable & Value & Source and Comments \\
\hline $\mathrm{C}_{\mathrm{V}}$ & 9000 & based on Table 2 by Van Cleve et al. [1983]. \\
\hline $\mathrm{N}_{\mathrm{V}}$ & 24 & based on Table 2 by Van Cleve et al. [1983]. \\
\hline $\mathrm{C}_{\mathbf{S}}$ & 11000 & based on Tables 9 and 13 by Van Cleve et al. [1983]. \\
\hline $\mathbf{N}_{\mathbf{S}}$ & 735 & based on Tables 10 and 13 by Van Cleve et al. [1983]. \\
\hline $\mathbf{N}_{\mathrm{AV}}$ & 0.6 & based on Weber and Van Cleve [1984]. \\
\hline GPP & 550 & see procedure described in methods. \\
\hline NPP & 220 & based on Table 3 by Van Cleve et al. [1983] and Oechel and Van Cleve [1986]. \\
\hline NPPSAT & 330 & based on Van Cleve and Zasada [1976]. \\
\hline NUPTAKE & 2.3 & $\begin{array}{l}\text { based on Table } 9.5 \text { by Oechel and Van Cleve [1986] and application of recycling estimates } \\
\text { from Tables } 3 \text { and } 7 \text { by Van Cleve et al. [1983]. }\end{array}$ \\
\hline NMOBIL & 1.9 & based on Tables 3 and 7 by Van Cleve et al. [1983]. \\
\hline
\end{tabular}

Assumes that vegetation typical of black spruce, white spruce, and upland hardwoods covers $80 \%, 10 \%$, and $10 \%$ of the landscape, respectively.

TABLE A5. Temperate Coniferous Forest: Andrews Experimental Forest, Watershed 10, Oregon

\begin{tabular}{|c|c|c|}
\hline Variable & Value & Source and Comments \\
\hline $\begin{array}{l}\mathrm{C}_{\mathrm{V}} \\
\mathrm{N}_{\mathrm{V}} \\
\mathrm{C}_{\mathrm{S}} \\
\mathrm{N}_{\mathrm{S}} \\
\mathrm{N}_{\mathrm{AV}} \\
\mathrm{GPP} \\
\mathrm{NPP} \\
\text { NPPSAT } \\
\text { NUPTAKE } \\
\text { NMOBIL }\end{array}$ & $\begin{array}{r}43500 \\
75 \\
21000 \\
420 \\
0.9 \\
2200 \\
535 \\
670 \\
4.2 \\
1.8\end{array}$ & $\begin{array}{l}\text { based on Table } 7 \text { by Grier and Logan [1977]. } \\
\text { based on Table } 2 \text { by Sollins et al. [1980]. } \\
\text { based on Table } 7 \text { by Grier and Logan [1977]. } \\
\text { based on Table } 2 \text { and Figure } 4 \text { by Sollins et al. [1980]. } \\
\text { based on Sollins et al. [1980] and Vitousek et al. [1982]. } \\
\text { see procedure described in methods. } \\
\text { based on Table } 10 \text { by Grier and Logan [1977]. } \\
\text { based on Peterson [1982]. } \\
\text { based on Figure } 3 \text { by Sollins et al. [1980]. } \\
\text { based on Figure } 3 \text { by Sollins et al. [1980]. }\end{array}$ \\
\hline
\end{tabular}

TABLE A6. Arid Shrubland: Curlew Valley, Utah

\begin{tabular}{|c|c|c|}
\hline Variable & Value & Source and Comments \\
\hline $\mathrm{C}_{\mathrm{V}}$ & 540 & based on Table 1 by Caldwell et al. [1977]. \\
\hline $\mathbf{N}_{\mathbf{V}}$ & 19.5 & based on Table 1 by Bjerregaard [1971]. \\
\hline $\mathrm{C}_{\mathrm{s}}$ & 11000 & based on Table 1 by Bjerregaard [1971]. \\
\hline $\mathbf{N}_{\mathbf{S}}$ & 800 & based on Table 1 by Bjerregaard [1971]. \\
\hline $\mathbf{N}_{\mathrm{AV}}$ & 1.6 & estimated. \\
\hline GPP & 235 & based on Figure 7 by Caldwell et al. [1977]. \\
\hline NPP & 110 & $\begin{array}{l}\text { modified from Figure } 7 \text { by Caldwell et al. [1977] based on below ground carbon allocation } \\
\text { analysis method of Raich and Nadelhoffer [1989]. }\end{array}$ \\
\hline NPPSAT & 120 & based on $10 \%$ response [Lajtha and Whitford, 1989]. \\
\hline NUPTAKE & 2.7 & $\begin{array}{l}\text { based on Figure } 7 \text { by Caldwell et al. [1977], Table } 1 \text { by Bjerregaard [1971], and } \\
25 \% \text { recycling [Lajtha, 1987]. }\end{array}$ \\
\hline NMOBIL & 0.9 & $\begin{array}{l}\text { based on Figure } 7 \text { by Caldwell et al. [1977], Table } 1 \text { by Bjerregaard [1971], and 25\% } \\
\text { recycling [Lajtha, 1987]. }\end{array}$ \\
\hline
\end{tabular}

Assumes that vegetation typical of the Atriplex confertifolia site and the Ceratoides lanata site covers $50 \%$ of the landscape, respectively. 
TABLE A7. Short Grassland: Central Plains Experimental Range, Colorado

\begin{tabular}{|c|c|c|}
\hline Variable & Value & Source and Comments \\
\hline $\mathrm{C}_{\mathrm{V}}$ & 315 & based on Table 1 by Clark [1977]. \\
\hline $\mathrm{N}_{\mathrm{V}}$ & 8.8 & based on Table 1 by Clark [1977]. \\
\hline $\mathrm{C}_{\mathrm{S}}$ & 3800 & based on Table 1 by Clark [1977]. \\
\hline $\mathrm{N}_{\mathrm{S}}$ & 390 & based on Table 1 by Clark [1977]. \\
\hline $\mathrm{N}_{\mathrm{AV}}$ & 2.0 & based on Table 1 by Woodmansee et al. [1978]. \\
\hline GPP & 388 & based on respiration budget at Osage Grassland in the work by Risser et al. [1981]. \\
\hline NPP & 200 & based on data by Sims and Singh [1978], Webb et al. [1983], and Burke et al. [1990]. \\
\hline NPPSAT & 400 & based on Dodd and Lauenroth [1979]. \\
\hline NUPTAKE & 3.5 & based on Woodmansee et al. [1978] and Schimel et al. [1985]. \\
\hline NMOBIL & 0.2 & based on $5 \%$ recycling (estimated). \\
\hline
\end{tabular}

TABLE A8. Tall Grassland: Osage prairie, Oklahoma

\begin{tabular}{lcl}
\hline Variable & Value & \multicolumn{1}{c}{ Source and Comments } \\
\hline $\mathrm{C}_{\mathrm{V}}$ & 650 & $\begin{array}{l}\text { based on Table 6.7 by Risser et al. [1981] and Table 2 of Connant and Risser [1974]. } \\
\text { based on Table 9.4 by Risser et al. [1981] and Table 3 by Bokhari and Singh [1975]. }\end{array}$ \\
$\mathrm{N}_{\mathrm{V}}$ & 6 & see Raich et al. [1991]. \\
$\mathrm{C}_{\mathrm{S}}$ & 16000 & see Raich et al. [1991]. \\
$\mathrm{N}_{\mathrm{S}}$ & 1550 & see Raich et al. [1991]. \\
$\mathrm{N}_{\mathrm{AV}}$ & 4.0 & based on respiration budget by Risser et al. [1981]. \\
$\mathrm{GPP}$ & 965 & based on Figure 6.4 and Table 9.7 by Risser et al. [1981]. \\
NPP & 425 & based on Table 10.30 by Risser et al. [1981]. \\
NPPSAT & 635 & see Raich et al. [1991]. \\
NUPTAKE & 5.5 & based on 10\% recycling [Risser et al. 1981, Figure 10.10]. \\
NMOBIL & 0.6 &
\end{tabular}

TABLE A9. Temperate Savanna: Cedar Creek Natural History Area, Minnesota

\begin{tabular}{|c|c|c|}
\hline Variable & Value & Source and Comments \\
\hline $\mathrm{C}_{\mathrm{V}}$ & 2100 & based on Table 6 by Ovington et al. [1963]. \\
\hline $\mathrm{N}_{\mathrm{V}}$ & 16 & $\begin{array}{l}\text { based on assuming } 88 \% \text { of biomass in forest with } C: N \text { of } 150 \text { and } 12 \% \text { of biomass in } \\
\text { grassland with } C: N \text { of } 75 .\end{array}$ \\
\hline $\mathrm{C}_{\mathbf{s}}$ & 4350 & based on Table 7 by Grigal et al. [1974]. \\
\hline $\mathbf{N}_{\mathbf{S}}$ & 400 & based on Table 7 by Grigal et al. [1974]. \\
\hline $\mathrm{N}_{\mathrm{AV}}$ & 4.3 & based on grassland and forest calibrations. \\
\hline GPP & 890 & based on grassland and forest calibrations. \\
\hline NPP & 450 & based on grassland and forest calibrations. \\
\hline NPPSAT & 720 & based on grassland and forest calibrations. \\
\hline NUPTAKE & 5.5 & based on grassland and forest calibrations. \\
\hline NMOBIL & 0.8 & based on $13 \%$ recycling (estimated). \\
\hline
\end{tabular}

Assumes that vegetation typical of tall grassland and deciduous forest each covers $50 \%$ of the landscape. Results from running the calibrations for tall grassland and temperate deciduous forest on the Cedar Creek grid cell were used to estimate some of the values for this site. 
TABLE A10. Temperate Deciduous Forest: Harvard Forest Hardwood Site, Massachusetts

\begin{tabular}{|c|c|c|}
\hline Variable & Value & Source and Comments \\
\hline $\mathrm{C}_{\mathrm{V}}$ & 15500 & based on McClaugherty et al. [1982] and K. J. Nadelhoffer (unpublished data, 1991). \\
\hline$N_{V}$ & 37 & $\begin{array}{l}\text { based on McClaugherty et al. [1982], Pastor et al. [1984], and J. D. Aber (unpublished data, } \\
\text { 1991). }\end{array}$ \\
\hline $\mathrm{C}_{\mathrm{s}}$ & 11250 & assume soil C:N of 20. \\
\hline $\mathbf{N}_{\mathbf{S}}$ & 560 & based on Figure 2 by Aber et al. [1983]. \\
\hline $\mathbf{N}_{\mathrm{AV}}$ & 2.0 & based on Vitousek et al. [1982]. \\
\hline GPP & 1410 & see procedure described in methods. \\
\hline NPP & 650 & $\begin{array}{l}\text { based on McClaugherty et al. [1982], Aber et al. [1983], and K. J. Nadelhoffer (unpublished } \\
\text { data, 1991). }\end{array}$ \\
\hline NPPSAT & 810 & based on $25 \%$ response (J. M. Melillo, personal communication, 1991). \\
\hline NUPTAKE & 8.0 & based on Figure 2 by Aber et al. [1983]. \\
\hline NMOBIL & 1.6 & based on $17 \%$ recycling (estimated). \\
\hline
\end{tabular}

Some of the values have been adjusted to account for the sandy soil texture of the grid cell.

Table A11. Temperate Mixed Forest: Harvard Forest, Massachusetts

\begin{tabular}{|c|c|c|}
\hline Variable & Value & Source and Comments \\
\hline $\begin{array}{l}\mathrm{C}_{\mathrm{V}} \\
\mathrm{N}_{\mathrm{V}}\end{array}$ & $\begin{array}{r}14800 \\
36\end{array}$ & $\begin{array}{l}\text { based on McClaugherty et al. [1982] and K. J. Nadelhoffer (unpublished data, 1991). } \\
\text { based on McClaugherty et al. [1982], Pastor et al. [1984], and J. D. Aber (unpublished data, } \\
\text { 1991). }\end{array}$ \\
\hline $\mathrm{C}_{\mathrm{S}}$ & 10700 & assumes soil C:N of 20 \\
\hline $\mathrm{N}_{\mathbf{S}}$ & 530 & based on Figure 2 by Aber et al. [1983]. \\
\hline $\mathbf{N}_{\mathrm{AV}}$ & 2.0 & based on Vitousek et al. [1982]. \\
\hline GPP & 1670 & see procedure described in methods. \\
\hline NPP & 650 & based on calibrations for deciduous and coniferous forests. \\
\hline NPPSAT & 810 & based on $25 \%$ response (J.M. Melillo, personal communication, 1991). \\
\hline NUPTAKE & 6.5 & based on Figure 2 by Aber et al. [1983] and coniferous forest calibration. \\
\hline NMOBIL & 2.0 & based on recycling in calibrations for deciduous and coniferous forests. \\
\hline
\end{tabular}

Assumes that vegetation typical of deciduous forest and coniferous forest covers $50 \%$ of the landscape, respectively. Data from the red pine plantation were used where appropriate. The calibration for temperate coniferous forest was run on the Harvard Forest grid cell to help estimate some of the values for this calibration.

TABLE A12. Temperate Broadleaved Evergreen Forest: Taita Experimental Station, North Island, New Zealand

\begin{tabular}{lcl}
\hline Variable & Value & \\
\hline $\mathrm{C}_{\mathrm{V}}$ & 15000 & \multicolumn{1}{c}{ Source and Comments } \\
$\mathrm{N}_{\mathrm{V}}$ & 42 & see Raich et al. [1991]. \\
$\mathrm{C}_{\mathrm{S}}$ & 13000 & see Raich et al. [1991]. \\
$\mathrm{N}_{\mathrm{S}}$ & 460 & see Raich et al. [1991]. \\
$\mathrm{N}_{\mathrm{AV}}$ & 1.0 & see Raich et al. [1991]. \\
$\mathrm{GPP}$ & 1700 & see Raich et al. [1991]. \\
$\mathrm{NPP}$ & 725 & see procedure described in methods. \\
NPPSAT & 810 & see Raich et al. [1991]. \\
NUPTAKE & 6 & based on 25\% response (estimated). \\
NMOBIL & 1.8 & based on 23\% recycling (same as for temperate mixed forest calibration).
\end{tabular}


TABLE A13. Tropical Savanna: Nylsvley Nature Reserve, South Africa

\begin{tabular}{|c|c|c|}
\hline Variable & Value & Source and Comments \\
\hline $\mathrm{C}_{\mathrm{V}}$ & 1500 & see Raich et al. [1991]. \\
\hline $\mathrm{N}_{\mathrm{V}}$ & 25 & see Raich et al. [1991]. \\
\hline $\mathrm{C}_{\mathrm{S}}$ & 8000 & see Raich et al. [1991]. \\
\hline $\mathbf{N}_{\mathbf{S}}$ & 400 & see Raich et al. [1991]. \\
\hline $\mathbf{N}_{\mathrm{AV}}$ & 2.0 & based on Frost [1985]. \\
\hline GPP & 1100 & $\begin{array}{l}\text { used assumption of } 80 \% \text { biomass in tropical deciduous forest and } 20 \% \text { in tall grassland } \\
\text { to define plant respiration parameter for this site. }\end{array}$ \\
\hline NPP & 435 & see Raich et al. [1991]. \\
\hline NPPSAT & 435 & based on assumption that productivity is not $\mathrm{N}$ limited. \\
\hline NUPTAKE & 10 & see Raich et al. [1991]. \\
\hline NMOBIL & 0.0 & estimated. \\
\hline
\end{tabular}

TABLE A14. Xeromorphic Forest: Guanica State Forest, Puerto Rico

\begin{tabular}{lcl}
\hline Variable & Value & \\
\hline $\mathrm{C}_{\mathrm{V}}$ & 4300 & \multicolumn{1}{c}{ Source and Comments } \\
$\mathrm{N}_{\mathrm{V}}$ & 90 & see Raich et al. [1991]. \\
$\mathrm{C}_{\mathrm{S}}$ & 11150 & see Raich et al. [1991]. \\
$\mathrm{N}_{\mathrm{S}}$ & 950 & see Raich et al. [1991]. \\
$\mathrm{N}_{\mathrm{AV}}$ & 5.0 & see Raich et al. [1991]. \\
$\mathrm{GPP}$ & 3150 & see Raich et al. [1991]. \\
NPP & 550 & see procedure described in methods. \\
NPPSAT & 550 & see Raich et al. [1991]. \\
NUPTAKE & 14 & based on assumption that productivity is not N limited. \\
NMOBIL & 0.0 & see Raich et al. [1991]. \\
\hline
\end{tabular}

TABLE A15. Tropical Deciduous Forest: Chakia, India

\begin{tabular}{lcl}
\hline Variable & Value & \\
\hline $\mathrm{C}_{\mathrm{V}}$ & 11350 & \multicolumn{1}{c}{ Source and Comments } \\
$\mathrm{N}_{\mathrm{V}}$ & 170 & see Raich et al. [1991]. \\
$\mathrm{C}_{\mathrm{S}}$ & 7900 & see Raich et al. [1991]. \\
$\mathrm{N}_{\mathrm{S}}$ & 950 & see Raich et al. [1991]. \\
$\mathrm{N}_{\mathrm{AV}}$ & 5.0 & see Raich et al. [1991]. \\
$\mathrm{GPP}$ & 5600 & estimated. \\
$\mathrm{NPP}$ & 700 & see procedure described in methods. \\
NPPSAT & 700 & see Raich et al. [1991]. \\
NUPTAKE & 27 & based on assumption that productivity is not N limited. \\
NMOBIL & 0.0 & see Raich et al. [1991]. \\
\hline
\end{tabular}


TABLE A16. Tropical Evergreen Forest: Ducke Forest, Manaus, Brazil

\begin{tabular}{lcl}
\hline Variable & Value & \\
\hline $\mathrm{C}_{\mathrm{V}}$ & 22500 & \multicolumn{1}{c}{ Source and Comments } \\
$\mathrm{N}_{\mathrm{V}}$ & 300 & see Raich et al. [1991]. \\
$\mathrm{C}_{\mathrm{S}}$ & 15000 & see Raich et al. [1991]. \\
$\mathrm{N}_{\mathrm{S}}$ & 900 & see Raich et al. [1991]. \\
$\mathrm{N}_{\mathrm{AV}}$ & 1.0 & see Raich et al. [1991]. \\
$\mathrm{GPP}$ & 8500 & see Raich et al. [1991]. \\
$\mathrm{NPP}$ & 1050 & see procedure described in methods. \\
NPPSAT & 1050 & see Raich et al. [1991]. \\
NUPTAKE & 24 & based on assumption that productivity is not N limited. \\
NMOBIL & 0.0 & see Raich et al. [1991]. \\
\hline
\end{tabular}

Acknowledgments. We thank E. A. Griffin, R. B. McKane, J. W. Raich, E. B. Rastetter, M. G. Ryan, P. A. Steudler, and two anonymous reviewers for their comments of the manuscript. Dan Martin produced the color plates and Marty Jesse assisted with the figures. This study was funded by the USDA Forest Service Resources Program and Assessment Staff, the National Aeronautics and Space Administration (NAGW-714 and NAS5-30558), the National Science Foundation (BSR-8718426), and the Andrew W. Mellon Foundation.

\section{REFERENCES}

Aber, J. D., J. M. Melillo, and C. A. Federer, Predicting the effects of rotation length, harvest intensity, and fertilization on fiber yield from northern hardwood forests in New England, For. Sci., 28, 31-48, 1982.

Aber, J. D., J. M. Melillo, C. A. McClaugherty, and K. N. Eshleman, Potential sinks for mineralized nitrogen following disturbance in forest ecosystems, Environ. Biogeochem., 35, 179-192, 1983.

Auchmoody, L. R., and H. C. Smith, Responses of yellow-poplar and red oak to fertilization in West Virginia, Soil Sci. Soc. Am. J., 41, 803-807, 1977.

Auclair, A. N. D., and A. N. Rencz, Concentration, mass, and distribution of nutrients in a subarctic Picea mariana-Cladonia alpestris ecosystem, Can. J. For. Res., 12, 947-968, 1982.

Bjerregaard, R. S., The nitrogen budget of two salt desert shrub plant communities of western Utah, Ph.D. dissertation, Utah State Univ., Logan, 1977.

Bokhari, U. G., and J. S. Singh, Standing state and cycling of nitrogen in soil-vegetation components of prairie ecosystems, Ann. Bot., 39, 273-285, 1975.

Bonan, G. B., H. H. Shugart, and D. L. Urban, The sensitivity of some high-latitude boreal forests to climatic parameters, Clim. Change, 16, 9-29, 1990.

Bowden, R. D., J. M. Melillo, and P. A. Steudler, Effects of nitrogen additions on annual nitrous oxide fluxes from temperate forest soils in the northeastern United States, J. Geophys. Res., 96, 9321-9328, 1991.

Burke, I. C., D. S. Schimel, W. J. Parton, C. M. Yonker, L. A. Joyce, and W. K. Lauenroth, Regional modeling of grassland biogeochemistry using GIS, Landscape Ecol., 4, 45-54, 1990.
Caldwell, M. M., R. S. White, R. T. Moore, and L. B. Camp, Carbon balance, productivity, and water use of cold-winter desert shrub communities dominated by $\mathrm{C}_{3}$ and $\mathrm{C}_{4}$ species, Oecologia, 29, 275-300, 1977.

Chapin, F. S. III, The mineral nutrition of wild plants, Ann. Rev. Ecol. Syst., 11, 233-260, 1980.

Chapin, F. S. III, Effects of multiple environmental stresses on nutrient availability and use, in Response of Plants to Multiple Stresses, edited by H. A. Mooney et al., pp. 67-88, Academic, San Diego, Calif., 1991a.

Chapin, F. S. III, Integrated responses of plants to stress, BioScience, 41, 29-36, $1991 \mathrm{~b}$.

Chapin, F. S. III, and R. A. Kedrowski, Seasonal changes in nitrogen and phosphorous fractions and autumn translocation in evergreen and deciduous taiga trees, Ecology, 64, 376-391, 1983.

Chapin, F. S. III, and L. Moilanen, Nutritional controls over nitrogen and phosphorous resorption from Alaskan birch leaves, Ecology, 72, 709-715, 1991.

Chapin, F. S. III, P. C. Miller, W. D. Billings, and P. I. Coyne, Carbon and nutrient budgets and their control in coastal tundra, in An Arctic Ecosystem: The Coastal Tundra at Barrow, Alaska, edited by J. Brown et al., pp. 458-482, Dowden, Hutchinson, and Ross, Stroudsburg, Pa., 1980.

Chapin, F. S. III, P. M. Vitousek, and K. Van Cleve, The nature of nutrient limitation in plant communities, Am. Natur., 127, 48-58, 1986.

Chapin, F. S. III, C. H. S. Walter, and D. T. Clarkson, Growth response of barley and tomato to nitrogen stress and its control by abscisic acid, water relations, and photosynthesis, Planta, 173, 352-366, 1988.

Clark, F. E., Internal cycling of ${ }^{15}$ nitrogen in shortgrass prairie, Ecology, 58, 1322-1333, 1977.

Clarkson, D. T., Factors affecting mineral nutrient acquisition by plants, Annu. Rev. Plant Physiol., 36, 77-115, 1985.

Cole, D. W., and M. Rapp, Elemental cycling in forest ecosystems, in Dynamic Properties of Forest Ecosystems, edited by D. E. Reichle, pp. 341-409, Cambridge University Press, New York, 1981.

Connant, S., and P. G. Risser, Canopy structure of a tall-grass prairie, J. Range Manag., 27, 313-318, 1974.

Conrad, R., Control of methane production in 
terrestrial ecosystems, in Exchange of Trace Gases Between Terrestrial Ecosystems and the Atmosphere, edited by M. O. Andreae and D. S. Schimel, pp. 39-58, John Wiley, New York, 1989.

Dodd, J. L., and W. K. Lauenroth, Analysis of the response of a grassland ecosystem to stress, in Perspectives in Grassland Ecology, edited by N. French, pp. 43-58, Springer-Verlag, New York, 1979.

Ellis, R. C., Response of crop trees of sugar maple, white ash, and black cherry to release and fertilization, Can. J. For. Res., 9, 179-188, 1979.

Emanuel, W. R., G. C. Killough, W. M. Post, and H. H. Shugart, Modeling terrestrial ecosystems in the global carbon cycle with shifts in carbon storage capacity by land-use change, Ecology, 65, 970-983, 1984.

Esser, G., Sensitivity of global carbon pools and fluxes to human and potential climatic impacts, Tellus Ser. $B$, 39, 245-260, 1987.

Evans, J. R., Nitrogen and photosynthesis in the flag leaf of wheat (Triticum aestivum L.), Plant Physiol., 72, 297-302, 1983.

Fitter, A. H., and R. K. M. Hay, Environmental Physiology of Plants, 355 pp., Academic, San Diego, Calif., 1981.

Frost, P. G. H., Organic matter and nutrient dynamics in a broadleafed African savanna, in Ecology and Management of the World's Savannas, edited by J. C. Tothill and J. J. Mott, pp. 200-206, Commonwealth Agricultural Bureaux, Slough, Engl., 1985.

Fung, I. Y., C. J. Tucker, and K. C. Prentice, Application of advanced very high resolution radiometer vegetation index to study atmospherebiosphere exchange of $\mathrm{CO}_{2}, J$. Geophys. Res., 92, 2999-3015, 1987.

Galbally, I. E., Factors controlling $\mathrm{NO}_{\mathbf{x}}$ emissions from soils, in Exchange of Trace Gases Between Terrestrial Ecosystems and the Atmosphere, edited by M. O. Andreae and D. S. Schimel, pp. 23-37, John Wiley, New York, 1989.

Giblin, A. E., K. J. Nadelhoffer, G. R. Shaver, J. A. Laundre, and A. J. McKerrow, Biogeochemical diversity along a riverside toposequence in arctic Alaska, Ecol. Monogr., 61, 415-435, 1991.

Gillette, D. A., and E. O. Box, Modeling seasonal changes of atmospheric carbon dioxide and carbon 13, J. Geophys. Res., 91, 5287-5304, 1986.

Grier, C. G., and R. S. Logan, Old-growth Pseudotsuga menziesii communities of a western Oregon watershed: Biomass distribution and production budgets, Ecol. Monogr., 47, 373-400, 1977.

Grigal, D. F., L. M. Chamberlain, H. R. Finney, D. V. Wroblewski, and E. R. Gross, Soils of the Cedar Creek Natural History Area, Miscell. Rep. 123, Agri. Exp. St., Univ. of Minnesota, Minneapolis, 1974.

Houghton, R. A., J. E. Hobbie, J. M. Melillo, B. Moore, B. J. Peterson, G. R. Shaver, and G. M. Woodwell, Changes in the carbon content of terrestrial biota and soils between 1860 and 1980: A net release of $\mathrm{CO}_{2}$ to the atmosphere, Ecol. Monogr., 53, 235-262, 1983.

Houghton, R. A., W. H. Schlesinger, S. Brown, and J. F.
Richards, Carbon dioxide exchange between the atmosphere and terrestrial ecosystems, in Atmospheric Carbon Dioxide and the Global Carbon Cycle, edited by J. R. Trabalka, pp. 113-140, Rep. DOE/ER-0239, U.S. Department of Energy, Washington, D.C., 1985.

Joint Federal-State Land Use Planning Commission for Alaska, Major Ecosystems of Alaska (map), U.S. Geological Survey, Washington, D. C., 1973.

Jonasson, S., and F. S. Chapin, III, Significance of sequential leaf development for nutrient balance of the cotton sedge, Eriophorum vaginatum L., Oecologia, 67, 511-518, 1985.

Jones, M. J. and A. Wild, Soils of the West African Savanna, Tech. Commun. 55, Commonwealth Agricultural Bureaux, Slough, Engl., 1975.

King, A. W., R. V. O'Neill, and D. L. DeAngelis, Using ecosystem models to predict regional $\mathrm{CO}_{2}$ exchange between the atmosphere and the terrestrial biosphere, Global Biogeochem. Cycles, 3, 337-361, 1989.

Kuchler, A. W., Potential Natural Vegetation of the Conterminous United States (map), American Geographical Society, New York, 1964.

Lajtha, K., Nutrient reabsorption efficiency and the response to phosphorus fertilization in the desert shrub Larrea tridentata (DC.) Cov., Biogeochemistry, 4, 265-276, 1987.

Lajtha, K., and W. G. Whitford, The effect of water and nitrogen amendments on photosynthesis, leaf demography, and resource-use efficiency in Larrea tridentata, a desert evergreen shrub, Oecologia, 80 , 341-348, 1989.

Larcher, W., Physiological Plant Ecology, 303 pp., Springer-Verlag, New York, 1980.

Lieth, H., Primary production: Terrestrial ecosystems, Human Ecol. , 1, 303-332, 1973.

Lieth, H., Modeling the primary productivity of the world, in Primary Productivity of the Biosphere, edited by $H$. Lieth and R. H. Whittaker, pp. 237-263, Springer-Verlag, New York, 1975.

Matson, P. A., and P. M. Vitousek, Cross-system comparisons of soil nitrogen transformations and nitrous oxide flux in tropical forest ecosystems, Global Biogeochem. Cycles, 1, 163-170, 1987.

Matson, P. A., P. M. Vitousek, and D. S. Schimel, Regional extrapolation of trace gas flux based on soils and ecosystems, in Exchange of Trace Gases Between Terrestrial Ecosystems and the Atmosphere, edited by M. O. Andreae and D. S. Schime1, pp. 97-108, John Wiley, New York, 1989.

Matthews, E., Vegetation, land-use, and albedo data archive, NASA Goddard Institute for Space Studies, New York, 1983.

McClaugherty, C. A., J. D. Aber, and J. M. Melillo, The role of fine roots in the organic matter and nitrogen budgets of two forested ecosystems, Ecology, 63, 1481-1490, 1982.

Melillo, J. M., J. D. Aber, P. A. Steudler, and J. D. Schimel, Denitrification potentials in a successional sequence of northern hardwood forest stands, Environ. Biogeochem., 35, 217-228, 1983. 
Mitchell, H. L., and R. F. Chandler, Jr., The nitrogen nutrition and growth of certain deciduous trees of northeastern United States. Black Rock For. Bull., 11, 1-94, 1939.

Mitchell, J. F. B., S. Manabe, V. Meleshko, and T. Tokioka, Equilibrium climate change - and its implications for the future, in Climate Change: The IPCC Scientific Assessment, edited by J. T. Houghton et al., pp. 131-172, Cambridge University Press, New York, 1990.

Mosier, A., D. Schimel, D. Valentine, K. Bronson, and W. Parton, Methane and nitrous oxide fluxes in native, fertilized, and cultivated grasslands, Nature, 350, 330-332, 1991.

Nadelhoffer, K. J., A. E. Giblin, G. R. Shaver, and A. E. Linkins, Microbial processes and plant nutrient availability in arctic soils, in Arctic Ecosystems in a Changing Climate, edited by F. S. Chapin et al., pp. 281-300, Academic, San Diego, Calif., 1991.

Oechel, W. C., and K. Van Cleve, The role of bryophytes in nutrient cycling in the taiga, in Forest Ecosystems in the Alaskan Taiga, edited by K. Van Cleve et al., pp. 121-137, Springer-Verlag, New York, 1986.

Ovington, J. D., D. Heitkamp, and D. B. Lawrence, Plant biomass and productivity of prairie, savanna, oakwood, and maize field ecosystems in central Minnesota, Ecology, 44, 52-63, 1963.

Parton, W. J., D. S. Schimel, C. V. Cole, and D. S. Ojima, Analysis of factors controlling soil organic matter levels in Great Plains grasslands, Soil Sci. Soc. Am. J., 51, 1173-1179, 1987.

Pastor, J., J. D. Aber, C. A. McClaugherty, and J. M. Melillo, Aboveground production and $\mathrm{N}$ and $\mathrm{P}$ cycling along a nitrogen mineralization gradient on Blackhawk Island, Wisconsin, Ecology, 65, 256-268, 1984.

Pastor, J., and W. M. Post, Influence of climate, soil moisture, and succession of forest carbon and nitrogen cycles, Biogeochemistry, 2, 3-27, 1986.

Pastor, J., and W. M. Post, Response of northern forests to $\mathrm{CO}_{2}$-induced climate change, Nature, $334,55-58$, 1988.

Peterson, C., Regional growth and response analysis for unthinned Douglas-fir, in Regional Forest Nutrition Research Project Biennial Report, 1980-82, pp. 3-25, University of Washington College of Forest Resources, Seattle, 1982.

Raich, J. W., and K. J. Nadelhoffer, Belowground carbon allocation in forest ecosystems: Global trends, Ecology, 70, 1346-1354, 1989.

Raich, J. W., E. B. Rastetter, J. M. Melillo, D. W. Kicklighter, P. A. Steudler, B. J. Peterson, A. L. Grace, B. Moore III, and C. J. Vorosmarty, Potential net primary productivity in South America: Application of a global model, Ecol. Appl., 1, 399-429, 1991.

Rastetter, E. B., M. G. Ryan, G. R. Shaver, J. M. Melillo, K. J. Nadelhoffer, J. E. Hobbie, and J. D. Aber, A general biogeochemical model describing the responses of the $\mathrm{C}$ and $\mathrm{N}$ cycles in terrestrial ecosystems to changes in $\mathrm{CO}_{2}$, climate, and $\mathrm{N}$ deposition, Tree Phys., 9, 101-126, 1991.

Ratliff, L. F., J. T. Ritchie, and D. K. Cassel, A survey of field-measured limits of soil water availability as related to laboratory-measured properties, Soil. Sci. Soc. Am. J., 47, 770-775, 1983.

Risser, P. G., E. C. Birney, H. D. Blocker, S. W. May, W. J. Parton, and J. A. Wiens, The True Prairie Ecosystem, 557 pp., Hutchinson Ross, Stroudsburg, Pa., 1981.

Rowe, J. S., Forest Regions of Canada, Publ. 1300, Dep. of Fish. and the Environ., Can. Forest Serv., Ottawa, 1972.

Ryan, M. G., A simple method for estimating gross carbon budgets for vegetation in forest ecosystems, Tree Phys., 9, 255-266, 1991 a.

Ryan, M. G., Effects of climate change on plant respiration, Ecol. Appl., 1, 157-167, $1991 \mathrm{~b}$.

Safford, L. O., and S. M. Filip, Biomass and nutrient content of 4-year-old fertilized and unfertilized hardwood stands, Can. J. For. Res., 4, 549-554, 1974.

Sanchez, P. A., E. E. Bandy, J. H. Villachica, and J. J. Nicholaides, Amazon Basin soils: Management for continuous crop production, Science, 216, 821-827, 1982.

Saxton, K. E., W. J. Rawls, J. S. Romberger, and R. I. Papendick, Estimating generalized soil-water characteristics from texture, Soil Sci. Soc. Am. J., 50, 1031-1036, 1986.

Schimel, D. S., M. A. Stillwell, and R. G. Woodmansee, Biogeochemistry of $C, N$, and $P$ in a soil catena of the shortgrass steppe, Ecology, 66, 276-282, 1985.

Schimel, D. S., W. J. Parton, T. G. F. Kittel, D. S. Ojima, and C. V. Cole, Grassland biogeochemistry: Links to atmospheric processes, Clim. Change, 17, 13-25, 1990.

Shaver, G. R., and F. S. Chapin III, Response to fertilization by various plant growth forms in an Alaskan tundra: Nutrient accumulation and growth, Ecology, 61, 662-675, 1980.

Shaver, G. R., and F. S. Chapin III, Effect of fertilization on production and biomass of tussock tundra, Alaska, U.S.A., Arct. Alp. Res., 18, 261-268, 1986.

Shaver, G. R., and F. S. Chapin III, Production:biomass relationships and element cycling in contrasting arctic vegetation types, Ecol. Monogr., 61, 1-31, 1991.

Shaver, G. R., K. J. Nadelhoffer, and A. E. Giblin, Biogeochemical diversity and element transport in a heterogeneous landscape, the North Slope of Alaska, in Quantitative Methods in Landscape Ecology, edited by M. Turner and R. Gardner, pp. 105-125, Springer-Verlag, New York, 1990.

Sims, P. L., and J. S. Singh, The structure and function of ten North American grasslands. III. Net primary production, turnover and efficiencies of energy capture and water use, J. Ecol., 66, 573-597, 1978.

Sollins, P., C. C. Grier, F. M. McCorison, K. Cromack, Jr., R. Fogel, and R. L. Fredriksen, The internal 
element cycles of an old-growth Douglas-fir ecosystem in western Oregon, Ecol. Monogr., 50, 261-285, 1980.

Steudler, P. A., R. D. Bowden, J. M. Melillo, and J. D. Aber, Influence of nitrogen fertilization on methane uptake in temperate forest soils, Nature, 341, 314-316, 1989.

Steudler, P., J. Melillo, R. Bowden, M. Castro, and A. Lugo, The effects of natural and human disturbance on soil nitrogen dynamics and trace gas fluxes in a Puerto Rican wet forest, Biotropica, 23, 356-363, 1992.

Van Cleve, K., and J. Zasada, Response of 70-year-old white spruce to thinning and fertilization in interior Alaska, Can. J. For. Res., 6, 145-152, 1976.

Van Cleve, K., L. Oliver, R. Schlentner, L. A. Viereck, and $\mathrm{C}$. T. Dyrness, Productivity and nutrient cycling in taiga forest ecosystems, Can. J. For. Res., 13, 747-766, 1983.

Vitousek, P. M., and R. W. Howarth, Nitrogen limitation on land and in the sea: How can it occur?, Biogeochemistry, 13, 87-115, 1991.

Vitousek, P. M., J. R. Gosz, C. C. Grier, J. M. Melillo, and W. A. Reiners, A comparative analysis of potential nitrification and nitrate mobility in forest ecosystems, Ecol. Monogr., 52, 155-177, 1982.

Vorosmarty, C. J., B. Moore III, A. L. Grace, M. P. Gildea, J. M. Melillo, B. J. Peterson, E. B. Rastetter, and $P$. A. Steudler, Continental scale models of water balance and fluvial transport: An application to South America, Global Biogeochem. Cycles, 3, 241-265, 1989.
Webb, W. L., W. K. Lauenroth, S. R. Szarek, and R. S. Kinerson, Primary production and abiotic controls in forests, grasslands, and desert ecosystems in the United States, Ecology, 64, 134-151, 1983.

Weber, M. G., and K. Van Cleve, Nitrogen transformations in feather moss and forest floor layers of interior Alaska black spruce ecosystems, Can. J. For. Res., 14, 278-290, 1984.

Woodmansee, R. G., J. L. Dodd, R. A. Bowman, F. E. Clark, and C. E. Dickinson, Nitrogen budget of a shortgrass prairie ecosystem, Oecologia, 34, 363-376, 1978.

A. L. Grace, B. Moore III, and C. J. Vorosmarty, Center for Complex Systems, Institute for the Study of Earth, Oceans, and Space, University of New Hampshire, Durham, NH 03824.

L. A. Joyce, Rocky Mountain Forest and Range Experiment Station, USDA Forest Service, Fort Collins, CO 80524.

A. D. McGuire, J. M. Melillo, and D. W. Kicklighter, The Ecosystems Center, Marine Biological Laboratory, Woods Hole, MA 02543.

(Received July 16, 1991; revised January 21, 1992; accepted January 27, 1992.) 